(c) American Dairy Science Association, 2004.

\title{
Portal Drained Visceral Flux, Hepatic Metabolism, and Mammary Uptake of Free and Peptide-Bound Amino Acids and Milk Amino Acid Output in Dairy Cows Fed Diets Containing Corn Grain Steam Flaked at 360 or Steam Rolled at $490 \mathrm{~g} / \mathrm{L}$
}

\author{
H. Tagari, ${ }^{\star}$ K. Webb Jr.,† B. Theurer,‡ T. Huber,‡ D. DeYoung,§ P. Cuneo, $\|$ \\ J. E. P. Santos, $\ddagger^{, 1}$ J. Simas, $\ddagger^{, 2}$ M. Sadik, $\ddagger$ A. Alio, $\ddagger$ O. Lozano, $\ddagger^{, 3}$ \\ A. Delgado-Elorduy, $\ddagger^{, 4}$ L. Nussio, $\ddagger^{, 5}$ C. Nussio, $\ddagger^{, 6}$ and F. Santos $\ddagger^{7}$ \\ *Department of Animal Sciences, Faculty of Agriculture, \\ The Hebrew University of Jerusalem, Rehovot, Israel 76100 \\ †Department of Animal and Poultry Sciences, \\ Virginia Polytechnic Institute and State University, Blacksburg, 24061 \\ ‡Department of Animal Sciences, University of Arizona, \\ Tucson 85721 \\ $\S$ Department of Veterinary Sciences, University of Arizona \\ |University Animal Care, University of Arizona
}

\section{ABSTRACT}

Objectives were to measure net fluxes of free (FAA) and peptide bound amino acids (AA) (PBAA) across portal-drained viscera (PDV), liver, splanchnic, and mammary tissues, and of milk AA output of lactating Holstein cows ( $n=6,109 \pm 9$ d in milk) as influenced by flaking density of corn grain. Cows were fed alfalfabased total mixed ration (TMR) containing $40 \%$ steamflaked (SFC) or steam-rolled corn (SRC) grain. The TMR were offered at 12 -h intervals in a crossover design. Six sets of blood samples were obtained from indwelling catheters in portal, hepatic, and mammary veins and mesenteric or costoabdominal arteries every $2 \mathrm{~h}$ from each cow and diet. Intake of dry matter $(18.4 \pm 0.4 \mathrm{~kg} /$ d), N, and net energy for lactation were not altered by corn processing. Milk and milk crude protein yields $(\mathrm{kg} /$ 12-h sampling) were 14.2 vs. 13.5 and 0.43 vs. 0.39 for

Received December 9, 2002.

Accepted June 2, 2003.

Corresponding author: H. Tagari; e-mail: tagari@agri.huji.il.

${ }^{1}$ Present address: Veterinary Training and Research Center, University of California-Davis, Tulare 93274.

${ }^{2}$ Present address: Elanco of Brasil, São Paulo, SP, Brasil 07180140 .

${ }^{3}$ Present address: Universidad Autonoma de Sinaloa, Escuela de Medicina Veterinariay Zootecnia, Apartado 1057, Culiacan, Sinaloa, Mexico, CP 80000.

${ }^{4}$ Present address: Dairy Nutrition Services of Mexico, S. A., de Cv, Piedras Negras No. 364, PIL, Gomez Palacio, Durango, CP 35078 Mexico.

${ }^{5}$ Present address: USP/ESALQ — Dept. Animal Science, Av. Padua Dias, 77, Piracicaba, SP, Brazil, 73418-900.

${ }^{6}$ Present address: Southeast Embrapa Cattle, PO Box 339, São Carlos, SP, Brasil, 13560-970.

${ }^{7}$ Present address: E. S. A. "Luiz De Queiroz"-USP, Av. Padua Dias \#11, Piracicaba, SP, Brazil, 13418-900.

cows fed SFC or SRC, respectively. The PDV flux of total essential FAA was greater (571.2 vs. $366.4 \mathrm{~g} / 12$ $h$, SEM 51.4) in cows fed SFC. The PDV flux of total essential PBAA was $69.3 \pm 10.8$ and $51.5 \pm 13.2 \mathrm{~g} / 12 \mathrm{~h}$ for cows fed SFC and SRC, respectively, and differed from zero, but fluxes of individual PBAA rarely differed between treatments. Liver flux of essential FAA was greater in cows fed SRC, but only the PBAA flux in cows fed SRC differed from zero. Splanchnic flux of FAA and PBAA followed the pattern of PDV flux, but variation was greater. Mammary uptake $(\mathrm{g} / 12 \mathrm{~h})$ of total essential FAA was greater in cows fed SFC than SRC (224.6 vs. 198.3, SEM 7.03). Mammary uptake of essential PBAA was 25.0 vs. 15.1 , SEM 5.2 , g/12 h for cows fed SFC or SRC, respectively, and differed from zero in half of the PBAA. Milk output of EAA was 187.8 vs 175.4 , SEM $4.4 \mathrm{~g} / 12 \mathrm{~h}$ in cows fed SFC and SRC, respectively, and output of most essential AA consistently tended to be greater in cows fed SFC. It is apparent that PBAA comprise a portion of total AA flux across $\mathrm{PDV}$ and are affected by grain processing. Further, this pool supplies an important component of AA taken up by the mammary gland. Quantifying the contribution of PBAA may improve diet formulation with respect to intestinal absorption and mammary uptake of AA.

(Key words: amino acid, peptide, dairy cow, flaked corn)

Abbreviation key: EAA = essential AA, FAA = free AA, GIT = gastrointestinal tract, $\mathbf{M E E}=$ mammary extraction efficiency, $\mathbf{M U}=$ mammary upake, $\mathbf{N E A A}=$ non-essential AA, PAH = $p$-aminohippuric acid, $\mathbf{P B}=$ peptide-bound, $\mathbf{P D V}$ = portal-drained viscera, $\mathbf{P B A A}=$ peptide bound AA, SFC = steam-flaked corn, $\mathbf{S R C}=$ steam-rolled corn. 


\section{INTRODUCTION}

Until recently, the belief was that intact proteins leaving the rumen are degraded exclusively in the small intestine and are absorbed there in the form of free AA (FAA) and that FAA in blood are the exclusive pool for tissue metabolism. Data accumulated during the last decade indicate a frequent failure of the predicted supply of AA from the FAA pool in the blood to fully satisfy the needs of the mammary gland for milk protein synthesis, and probably for metabolism (Guinard and Rulquin, 1994; Metcalf et al., 1996; Bequette et al., 1999). Evidence that FAA from blood may be insufficient to meet tissue needs (Schwab et al., 1976; Vanhatalo et al., 1999) along with evidence for transport of peptidebound (PB) AA (PBAA) from the gastrointestinal tract (GIT; Koeln et al., 1993) suggests that sources other than FAA, namely proteins and/or PBAA, may contribute to meeting tissue needs. These findings brought the AFRC (1991) to state that: "The possible role of peptides (in addition to FAA), in the supply of AA N, would have major implications on the development of systems used to evaluate protein supply for ruminants."

There has been controversy, however, regarding methods employed to quantify PBAA and PBAA fluxes across tissues. At issue was the completeness of plasma protein removal by various precipitation methods and the ability to accurately quantify small arteriovenous differences. Variable contributions of PBAA to the total concentration of FAA plus PBAA in arterial plasma have been reported (65\%, Koeln et al., 1993; 26 to $28 \%$, Seal and Parker, 1996; 38\%, Remond et al., 2000). Likewise, variable contributions of PBAA to the total portaldrained visceral (PDV) flux of FAA and PBAA have been reported (89\%, Koeln et al., 1993; 57 to $63 \%$, Seal and Parker, 1996; 36 to 47\%, Remond et al., 2000). That positive fluxes of PBAA across nonmesenteric-drained viscera have been reported suggests the possibility that there is preintestinal absorption of PBAA (Webb et al., 1993; Seal and Parker, 1996; Remond et al., 2000).

Less controversial is the evidence for the contributions of PBAA for milk protein synthesis and mammary metabolism. Results from in vivo studies indicate that the caprine mammary gland uses PBAA for milk protein synthesis (Backwell et al., 1996; Bequette et al., 1999). Met-containing peptides were reported to be used as Met sources for synthesis of secreted proteins by mammary tissue explants from mice (Wang et al., 1996) and for protein accretion in cultured MAC-T cells (Pan et al., 1996).

That diet can influence PDV flux of PBAA became known when lambs that were infused ruminally with CN had nearly twice the PDV flux of PBAA as did lambs not infused with CN (Remond et al., 2000). Therefore, it may well be that diets differing in RUP, ruminal microbial CP outflow, or composition of proteins may influence PBAA flux across the GIT and, consequently, PBAA availability for tissue utilization.

We hypothesize that PBAA are absorbed and are sources of AA for the mammary gland. The present study was conducted with lactating dairy cows fed regular dairy diets containing either steam-rolled (SRC) or steam-flaked corn (SFC) grain. The objective was to quantify the PDV, splanchnic, and hepatic fluxes of FAA and PBAA. In addition, mammary uptake (MU) from FAA and PBAA pools were compared with milk AA output.

\section{MATERIALS AND METHODS}

\section{Cows and Diets}

Animal care and housing, surgical preparation of cows, and sampling and analytical protocols were described in greater detail in a companion paper (DelgadoElorduy et al., 2002a). Briefly, 6 early-lactation Holstein cows (109 \pm 9 DIM; 4 first lactation, 2 second lactation) were randomly assigned to 2 dietary treatments in a crossover design to determine the flux of plasma FAA and PBAA across PDV, liver, splanchnic, and mammary tissues, and the effect on milk yield and milk protein and AA output. Diets differed only in the method of processing the corn, which was described in full by Delgado-Elorduy et al. (2002b). Diets contained either SFC or SRC of densities of 360 and $490 \mathrm{~g} / \mathrm{L}$, respectively. The SFC and SRC were mixed in TMR the same day as they were processed using an augertype mixing wagon (Kirby, Inc., Tulare, CA). For the first period, 3 cows received the diet containing SRC and 3 cows received the diet containing SFC. The diets were switched for period 2. Cows were housed in partially shaded, individual pens where they had ad libitum access (10\% refusals) to TMR containing $36 \%$ alfalfa hay and $40 \%$ grain (Table 1). Diets were offered at 0600 and $1800 \mathrm{~h}$ daily. Cows were adapted to diets for an average of $11 \mathrm{~d}$ (range $=7$ to $14 \mathrm{~d}$ ) before blood sampling.

\section{Surgery, Blood Collection, and Blood Flow Measurements}

Surgery, blood collection, and blood flow measurements were as described earlier (Delgado-Elorduy et al., 2002a). Surgical procedures and care of cows were approved by the University of Arizona Institutional Animal Care and Use Committee (Approval \#94-128-87). Lactating cows were surgically implanted ( $22 \pm 3$ DIM) with indwelling catheters in mesenteric, portal, and hepatic veins and the mesenteric artery. Procedures 
Table 1. Ingredient and chemical analyses of experimental TMR with processed corn grain.

\begin{tabular}{|c|c|c|c|}
\hline Item & \multicolumn{2}{|c|}{ Percent TMR } & \\
\hline \multicolumn{4}{|l|}{ Ingredient } \\
\hline \multicolumn{2}{|l|}{ Alfalfa hay } & & \\
\hline Corn grain ${ }^{1}$ & & & \\
\hline Whole cottonseed & \multicolumn{2}{|c|}{10.0} & \\
\hline Soybean meal & \multicolumn{2}{|c|}{8.0} & \\
\hline Cottonseed hulls & \multicolumn{2}{|c|}{3.0} & \\
\hline Minerals and vitamin $\operatorname{mix}^{2}$ & \multicolumn{2}{|c|}{3.0} & \\
\hline Chemical analyses (DM basis) & Steam-rolled & Steam-flaked & SEM \\
\hline $\mathrm{DM}$ & 85.17 & 84.89 & 0.46 \\
\hline Starch & 30.01 & 30.61 & 0.10 \\
\hline $\mathrm{CP}^{3}$ & 16.15 & 16.77 & 0.43 \\
\hline $\mathrm{N}$ & 2.58 & 2.68 & 0.07 \\
\hline NDF & 29.30 & 28.74 & 0.22 \\
\hline $\mathrm{ADF}$ & 17.89 & 18.03 & 0.25 \\
\hline $\mathrm{NE}_{\mathrm{L}},{ }^{4} \mathrm{Mcal} / \mathrm{kg} \mathrm{DM}$ & 1.73 & 1.78 & - \\
\hline \multicolumn{4}{|c|}{${ }^{1}$ Density: steam-rolled = $490 \mathrm{~g} / \mathrm{L}(38 \mathrm{lb} / \mathrm{bu}) ;$ steam-flaked = $360 \mathrm{~g} / \mathrm{L}(28 \mathrm{lb} / \mathrm{bu})$} \\
\hline \multicolumn{4}{|c|}{$\begin{array}{l}{ }^{2} \text { Composition: } 2.5 \% \mathrm{NaHCO}_{3}, 13 \% \mathrm{MgO}, 1 \% \text { niacin, } 0.5 \% \text { Zinpro } 40,22 \% \mathrm{Ca}_{2} \mathrm{PO}_{4}, 6.6 \% \mathrm{NaCl}, 2.3 \% \mathrm{~S} \text {, } \\
3.30 \mathrm{ppm} \text { of } \mathrm{Co}, 3.30 \mathrm{ppm} \mathrm{Cu}, 20 \mathrm{ppm} \text { of I, } 1300 \mathrm{ppm} \text { of } \mathrm{Mn}, 10 \mathrm{ppm} \text { of } \mathrm{Se}, 2000 \mathrm{ppm} \text { of } \mathrm{Zn}, 67,000 \mathrm{IU} / \mathrm{kg} \\
\text { of vitamin } \mathrm{A}, 6700 \mathrm{IU} / \mathrm{kg} \text { of vitamin } \mathrm{D}, 700 \mathrm{IU} / \mathrm{kg} \text { of vitamin } \mathrm{E} \text { and molasses (carrier). } \\
{ }^{3} \text { Dietary } \mathrm{N} \times 6.25 \text {. }\end{array}$} \\
\hline \multicolumn{4}{|c|}{$\begin{array}{l}{ }^{4} \text { Estimated from Theurer et al. (1997) for corn grains (2.22 and 2.10 Mcal/kg DM for SF vs. SR, respectively), } \\
\text { and NRC (Theurer et al., 1999) for other feeds. }\end{array}$} \\
\hline
\end{tabular}

for catheter implantation and maintenance of patency were as described by Huntington et al. (1989), except for catheterization of the hepatic vein, which was performed with the assistance of a linear ultrasound scanner equipped with a 5.0 MHZ probe (Aloka-500V, Corometrics Medical Systems Inc., New Haven, CT) to locate the vein and to confirm placement of the catheter. Temporary catheters for sampling blood from the mammary vein were implanted 1 to $2 \mathrm{~d}$ before sampling in the subcutaneous abdominal (mammary) vein, and the tip was guided backwards by palpation and placed as close as possible to the udder ( 2 to $5 \mathrm{~cm}$ ). Two cows lost patency of hepatic catheters. Two cows lost patency of mesenteric artery catheters, and these were replaced by inserting a catheter into a costoabdominal artery as described by Haibel et al. (1989).

During sampling, cows were infused with a sterile aqueous solution ( $\mathrm{pH} 7.4$ ) of $p$-aminohippurric acid (PAH; 10\%, wt/vol), which began $40 \mathrm{~min}$ prior to blood collection. Blood samples were drawn simultaneously from the artery, portal, hepatic, and mammary veins into heparinized syringes, 5 to $7 \mathrm{~min}$ before completion of PAH infusion. Six sets of each of the 4 samples were collected at 2-h intervals, starting before the first milking at $0600 \mathrm{~h}$. Syringes containing the samples were immersed in an ice slurry $\left(0\right.$ to $\left.1^{\circ} \mathrm{C}\right)$. Then plasma was harvested from the individual blood samples, and a methanol filtrate was prepared (Delgado-Alorduy et al., 2002a). The individual filtrates were pooled into one sample/cow per day as previously described for FAA (Delgado-Alorduy et al., 2002a). Concentrations of PAH in blood samples were determined as described by Eisenman et al. (1987).

\section{Feed and Milk Collection and Analysis}

Feed and ort samples were obtained for 5 to $7 \mathrm{~d}$ prior to and on the day of sampling and were pooled for each cow and diet. Milk production was recorded daily and milk samples were collected twice daily for $4 \mathrm{~d}$ before and on the day of blood sampling. To enable the study of the relationship between PDV net appearance and MU of FAA and PBAA compared with AA secretion in milk, an extra milk sample was collected from the p.m. milking on the day of sampling.

Diets and orts were analyzed for DM, N, CP, total starch, NDF, and ADF. Daily milk samples were analyzed for protein using infrared procedures. Analytical protocols for all of these analyses were as described previously (Delgado-Elorduy et al., 2002a).

\section{FAA and PBAA Determination in Plasma and AA in Milk}

The AA composition of milk proteins and the FAA composition of milk and plasma were determined by protocols described previously (Delgado-Elorduy et al., 2002a). Briefly, methanol supernatants were filtered through passivated, Amicon Centricon YM-3 filter devices (Millipore Corporation, Bedford, MA) that had a cut-off of $3000 \mathrm{MW}$. Filtrates were collected in microcentrifuge tubes (catalog no. 05-664-34, Fisher Scientific, Pittsburgh, PA), purged with $\mathrm{N}_{2}$, and stored refriger- 
ated $\left(2^{\circ} \mathrm{C}\right)$ until analyzed. Filtered samples were analyzed for FAA and PBAA by HPLC using the Waters Pico-Tag method (Bidlingmeyer et al., 1984). Samples for PBAA were hydrolyzed in a $\mathrm{HCl}$ vapor at $112^{\circ} \mathrm{C}$ for $24 \mathrm{~h}$ prior to analysis. The $\mathrm{HCl}$ (constant boiling, catalog no. 24309, Pierce, Rockford, IL) contained sodium sulfite $(0.1 \%, \mathrm{wt} / \mathrm{vol})$ and phenol $(1.1 \mathrm{mg} / \mathrm{mL})$. Replicate analyses for FAA and PBAA from a particular sample were performed consecutively. The AA content of hydrolyzed samples was corrected for losses occurring during hydrolysis (Delgado-Elorduy et al., 2002a). The PBAA content of samples was calculated as the difference between the corrected AA content of hydrolyzed filtrates and the FAA content of filtrates. Recoveries for PB-Tyr following hydrolysis were very poor, hence, data for this PBAA are not presented.

\section{Calculations of Blood Flow}

Blood flow in portal and hepatic veins was calculated by downstream dilution of PAH as described by Katz and Bergman (1969), and was as follows:

$$
\mathrm{BF}=\left(\mathrm{PAH}_{\mathrm{IR}} \div \mathrm{PAH}_{[\mathrm{V}-\mathrm{A}]}\right),
$$

where $\mathrm{BF}$ is blood flow $(\mathrm{L} / \mathrm{h}), \mathrm{PAH}_{\mathrm{IR}}$ is infusion rate of $\mathrm{PAH}(15,000 \mathrm{mg} / \mathrm{h})$, and $\mathrm{PAH}_{[\mathrm{V}-\mathrm{A}]}$ is venoarterial concentration differences of $\mathrm{PAH}(\mathrm{mg} / \mathrm{L})$. Hepatic artery blood flow (HABF) was calculated as the difference between hepatic and portal vein flows. Mammary blood flow was determined and calculated by Fick's principle as previously described (Delgado-Elorduy et al., 2002a).

To determine the proportion of plasma in whole blood, calculations were corrected for plasma contained in the packed cell portion of the hematocrit based on the assumption that $20 \%$ of the packed cell volume was plasma (Elwyn, 1966). Hematocrits of blood samples collected from different vessels were remarkably constant and varied only minimally $(28.4 \pm 0.04 \%)$ among animals. Therefore, an average corrected hematocrit value was used to calculate plasma flow by multiplying the blood flow by 0.7728 (proportion of corrected plasma in blood).

\section{Calculation of Net Fluxes of FAA and PBAA}

Calculations of net fluxes of FAA and PBAA (g/12 h) across PDV, liver, and splanchnic tissues, were as follows:

$$
\begin{gathered}
\mathrm{XF}_{\mathrm{PDV}}=\mathrm{PPF} \times \mathrm{X}_{[\mathrm{P}-\mathrm{A}]}, \\
\mathrm{XF}_{\text {Liver }}=\left(\mathrm{HAPF} \times \mathrm{X}_{[\mathrm{H}-\mathrm{A}]}\right)+\left(\mathrm{PPF} \times \mathrm{X}_{[\mathrm{H}-\mathrm{P}]}\right), \text { and } \\
\mathrm{XF}_{\text {Splanchnic }}=\mathrm{HPF} \times \mathrm{X}_{[\mathrm{H}-\mathrm{A}]},
\end{gathered}
$$

where $\mathrm{XF}_{\mathrm{PDV}}, \mathrm{XF}_{\mathrm{Liver}}$, and $\mathrm{XF}_{\text {Splanchnic }}$ are net fluxes of FAA or PBAA (g/12 h) of PDV, liver, and splanchnic tissues, respectively, PPF, HAPF, and HPF are portal vein, hepatic artery, and hepatic vein plasma flows, respectively, and $\mathrm{X}_{[\mathrm{P}-\mathrm{A}]}, \mathrm{X}_{[\mathrm{H}-\mathrm{A}]}$, and $\mathrm{X}_{[\mathrm{H}-\mathrm{P}]}$ are portal-arterial, hepatic-arterial, and hepatic-portal differences (mg/L) for X (FAA or PBAA), respectively.

Calculations of liver extraction efficiency (LEE) were as follows:

$$
\begin{aligned}
\mathrm{LEE}= & 100 \times\left\{\left(\mathrm{PPF} \times \mathrm{X}_{[\mathrm{P}-\mathrm{H}]}\right)+\left(\mathrm{HAPF} \times \mathrm{X}_{[\mathrm{A}-\mathrm{H}]}\right)\right\} \\
& \div\left\{\left(\mathrm{PPF} \times \mathrm{X}_{\mathrm{P}}\right)+\left(\mathrm{HAPF} \times \mathrm{X}_{\mathrm{A}}\right)\right\},
\end{aligned}
$$

where LEE denotes liver extraction efficiency (\%) and $\mathrm{X}_{\mathrm{A}}$ and $\mathrm{X}_{\mathrm{P}}$ denotes the concentrations $(\mathrm{mg} / \mathrm{L})$ of FAA or PBAA in plasma of the artery and portal veins, respectively. $\mathrm{X}_{[\mathrm{P}-\mathrm{H}]}$ and $\mathrm{X}_{[\mathrm{A}-\mathrm{H}]}$ are portal-hepatic and arterialhepatic differences for FAA or PBAA $(\mathrm{mg} / \mathrm{L})$, respectively.

Mammary uptake or mammary flux $\left(\mathrm{XF}_{\mathrm{M}}, \mathrm{g} / 12 \mathrm{~h}\right)$ of FAA or PBAA and mammary extraction efficiency, \% (MEE) were calculated according to Brockman and Bergman (1975) as:

$\mathrm{MU}=\mathrm{MPF} \times \mathrm{FAA}_{[\mathrm{A}-\mathrm{M}]}$ or $\mathrm{MU}=\mathrm{MPF} \times \mathrm{PBAA}_{[\mathrm{A}-\mathrm{M}]}$ and
$\mathrm{MEE}=100 \times(\mathrm{A}-\mathrm{M}) \div \mathrm{A}$,

$$
\mathrm{MEE}=100 \times(\mathrm{A}-\mathrm{M}) \div \mathrm{A} \text {, }
$$

where $\mathrm{FAA}_{[\mathrm{A}-\mathrm{M}]}$ and $\mathrm{PBAA}_{[\mathrm{A}-\mathrm{M}]}=$ concentration differences between arterial plasma and mammary vein plasma for FAA and PBAA, respectively. $\mathrm{MPF}=$ mammary plasma flow and $\mathrm{A}$ and $\mathrm{M}$ are artery and mammary vein concentrations $(\mathrm{mg} / \mathrm{L})$, respectively of FAA or PBAA.

Concentration of PB Glu + Gln and PB Asp + Asn were calculated assuming that all free or PB-Gln and PB-Asn were converted quantitatively during hydrolysis to Glu and Asp and were determined as such, hence the equation was as follows:

$$
\text { PB-Glu + PB-Gln = TH Glu }-(\text { Glu + Gln }),
$$

where TH-Glu = total Glu in the hydrolyzate, PB-Glu or PB-Gln = peptide-bound Glu or Gln and Glu or Gln = free Glu or Gln.

\section{Statistical Analysis}

Plasma concentrations, nutrient fluxes, and lactational performance data were analyzed by ANOVA using the general linear model procedure previously outlined (Delgado-Elorduy et al., 2002a). Significance of difference from zero was examined by $t$-test. Associations between variables were expressed by Pearson correlation coefficients. Significance for performance data 
Table 2. Intake and lactational performance of dairy cows fed diets containing steam-flaked (SFC) or steamrolled (SRC) corn grain.

\begin{tabular}{lcccc}
\hline & \multicolumn{3}{c}{ Diet } & \\
\cline { 2 - 3 } Item & SFC & SRC & SEM & $P$ \\
\hline Cows & 6 & 6 & & \\
Intake, kg/d & & & & \\
DM & 18.49 & 18.24 & 0.36 & 0.65 \\
CP & 3.099 & 2.948 & 0.092 & 0.30 \\
N & 0.496 & 0.472 & 0.015 & 0.30 \\
NE, Mcal/d (Calculated) & 32.900 & 31.580 & 0.630 & 0.20 \\
Milk yields, of sampling day & & & & 0.18 \\
Total, kg/12 h & 14.2 & 13.5 & 0.012 & 0.069 \\
CP (DHI), kg/12 h & 0.43 & 0.39 & 0.3 & NS \\
CP (DHI), \% & 3.0 & 3.0 & 0.094 & 0.16 \\
Total AA, kg/12 h & 0.389 & 0.365 & 0.044 & 0.13 \\
Total essential AA (w/o Trp), kg/12 h & 0.188 & 0.175 & & \\
\hline
\end{tabular}

and for plasma nutrient concentrations were declared at $P<0.05$ and tendencies at $P<0.10$, whereas for FAA and PBAA fluxes, ratios, or efficiencies, significance was declared at $P<0.10$ and tendencies at $P>0.10$ to to $P$ $<0.2$.

\section{RESULTS}

Results of performance related to milk production, milk N, milk protein, and milk AA yields are reported for the 12-h blood-sampling period. Also reported are PDV, hepatic, splanchnic, and mammary fluxes of FAA and PBAA. The results for the full experimental period were published earlier (Delgado-Adulroy et. al., 2002b).

\section{Feed Intake and Lactational Performance of Cows}

Dry matter intake $(\mathrm{kg} / \mathrm{d})$ for the whole experimental period was similar for cows fed SRC compared with SFC (Table 2). Milk yield (kg/12 h) was 14.2 and 13.5 $\mathrm{kg} / 12 \mathrm{~h}(P<0.05)$, for cows fed SFC and SRC, respectively. Milk CP yield was greater $(P<0.069)$ for cows fed the SFC diet than for cows fed the SRC (0.43 and $0.39 \mathrm{~kg} / 12 \mathrm{~h}$, respectively).

\section{Portal, Hepatic, and Mammary Vein and Arterial Concentrations of FAA and PBAA}

Except for PB-Phe in the portal vein in cows of both treatments and PB-Ala, PB-Arg, PB-Asp, PB-Pro, PBSer, and PB-Thr in the hepatic vein of cows fed the SFC diets, concentrations of all individual FAA or PBAA differed $(P<0.01$ to 0.001 ) from zero (Tables 3 , 4 , and 5 ).

Arterial concentrations of total essential AA (EAA) tended to be lower $(P<0.15)$ in the plasma of cows fed SFC (Table 3). Arginine and Thr were lower $(P<0.03$ and 0.02, respectively), whereas Asp, Gln, Ile, Leu, Phe, and Pro only tended ( $P<0.13$ to 0.19$)$ to be lower. In the PBAA pool, concentrations of PB-Ile, PB-Ser, and PB-Val were lower $(P<0.03$ to 0.06$)$ in cows fed the SFC diet, while concentrations of PB-Pro, PB-Orn, and PB-Gly only tended $(P<0.14$ to 0.17$)$ to be so.

Portal concentrations of FAA and PBAA were similar in cows fed SFC and SRC (Table 4). Hepatic concentrations of FAA and PBAA were slightly lower than those observed in the portal vein (NS) and were similar between treatments (Table 5). Only levels of Asp and Thr were lower $(P<0.07$ and 0.06 , respectively) in cows fed SFC. Regarding concentrations of PBAA in the hepatic vein in comparison to the portal vein, fewer differed significantly from zero, which may be attributed to processing by the liver. However, concentrations of PBHis, PB-Lys, PB-Met, and PB-Thr of the EAA differed from zero $(P<0.001$ to 0.1$)$, and PB-Arg tended to be so. Concentrations of all $\mathrm{PB}$ branched chain $\mathrm{AA}$ and PB-Phe did not differ from zero.

Mammary vein concentrations of both FAA and PBAA (Table 6) were affected by diet for more AA than was observed for concentrations in arterial (Table 3) or hepatic (Table 5) plasma. This could be expected in view of the differences in milk and protein output (Table 2). Accordingly, concentrations of Arg, Ile, Leu, Orn, Pro, Thr, Val, and total EAA were lower $(P<0.025$ to 0.09$)$ when the cows were fed the SFC diet compared with the SRC diet. Concentrations of Asp, Lys, Phe, and total AA tended $(P<0.12$ to 0.18$)$ to be lower when cows were fed SFC. The same trend was observed for PBAA in the mammary vein, where concentrations were lower in cows fed SFC. Concentrations of PB-Arg, PB-Orn, PB-Ser, PB-Thr, and total PB-EAA were lower $(P<$ 0.04 to 0.1 ), and there was a tendency towards lower concentrations of PB-Ala, PB-Gly, PB-Leu, PB-Lys, total PB-nonessential AA (NEAA), and total PBAA $(P<$ 0.12 to 0.19 ) in cows that were fed SFC. Of the PBAA, only the concentrations of PB-Phe and PB-Ile in cows 
Table 3. Arterial concentrations (mg/L) of free (FAA) and peptide bound amino acids (PBAA) in plasma of cows fed steam-flaked (SFC) or steam-rolled corn (SRC) to densities of 360 or $490 \mathrm{~g} / \mathrm{L}(\mathrm{n}=6)$.

\begin{tabular}{|c|c|c|c|c|c|c|c|c|c|c|c|c|}
\hline \multirow{3}{*}{$\begin{array}{l}\text { Pool } \\
\text { Diet } \\
\text { Amino acid }\end{array}$} & \multicolumn{6}{|c|}{ FAA } & \multicolumn{6}{|c|}{ PBAA } \\
\hline & \multirow{2}{*}{$\frac{\mathrm{SFC}}{\text { Mean }}$} & \multirow[b]{2}{*}{$P^{1}$} & \multicolumn{2}{|l|}{$\mathrm{SRC}$} & \multirow[b]{2}{*}{$\mathrm{SEM}^{2}$} & \multirow[b]{2}{*}{$P^{3}$} & \multirow{2}{*}{$\frac{\mathrm{SFC}}{\text { Mean }}$} & \multirow[b]{2}{*}{$P^{1}$} & \multirow{2}{*}{$\frac{\mathrm{SRC}}{\text { Mean }}$} & \multirow[b]{2}{*}{$P^{1}$} & \multirow[b]{2}{*}{$\mathrm{SEM}^{2}$} & \multirow[b]{2}{*}{$P^{3}$} \\
\hline & & & Mean & $P^{1}$ & & & & & & & & \\
\hline Ala & 22.5 & $*$ & 24.7 & * & 1.4 & 0.32 & 3.0 & * & 3.5 & * & 0.7 & 0.64 \\
\hline Arg & 11.7 & * & 13.5 & * & 0.4 & 0.03 & 1.5 & * & 1.9 & * & 0.2 & 0.31 \\
\hline Asn & 3.8 & $*$ & 3.6 & * & 0.9 & 0.90 & & & & & & \\
\hline Asp & 1.8 & $*$ & 3.0 & * & 0.5 & 0.14 & 3.6 & $*$ & 3.3 & * & 0.7 & 0.75 \\
\hline Cit & 15.9 & $*$ & 18.0 & * & 1.5 & 0.38 & 14.2 & $*$ & 15.3 & * & 1.4 & 0.61 \\
\hline Gln & 17.0 & $*$ & 19.7 & * & 1.0 & 0.13 & & & & & & \\
\hline Glu & 8.0 & $*$ & 8.3 & * & 0.4 & 0.65 & 9.2 & $*$ & 11.0 & * & 2.1 & 0.57 \\
\hline Gly & 19.3 & $*$ & 20.4 & * & 1.7 & 0.65 & 28.5 & $*$ & 32.8 & $*$ & 1.9 & 0.17 \\
\hline His & 6.1 & $*$ & 6.6 & * & 0.5 & 0.51 & 4.0 & $*$ & 4.6 & $*$ & 0.5 & 0.45 \\
\hline Нyр & 2.2 & * & 2.3 & * & 0.2 & 0.51 & 0.9 & * & 1.0 & & 0.1 & 0.50 \\
\hline Ile & 15.3 & $*$ & 17.2 & * & 0.8 & 0.15 & 0.3 & $*$ & -0.1 & & 0.1 & 0.06 \\
\hline Leu & 21.4 & $*$ & 24.2 & * & 1.2 & 0.18 & 1.7 & $*$ & 1.6 & * & 0.3 & 0.85 \\
\hline Lys & 8.3 & $*$ & 8.8 & * & 0.5 & 0.49 & 2.6 & $*$ & 2.5 & $*$ & 0.3 & 0.83 \\
\hline Met & 2.9 & $*$ & 3.3 & * & 0.4 & 0.52 & 1.8 & $*$ & 1.6 & * & 0.4 & 0.67 \\
\hline Orn & 3.8 & $*$ & 4.5 & * & 0.3 & 0.20 & 2.3 & $*$ & 2.9 & * & 0.2 & 0.14 \\
\hline Phe & 8.5 & $*$ & 9.9 & * & 0.7 & 0.19 & 0.4 & \# & 0.3 & \# & 0.2 & 0.84 \\
\hline Pro & 10.9 & $*$ & 12.6 & $*$ & 0.6 & 0.13 & 1.7 & $*$ & 1.3 & * & 0.1 & 0.14 \\
\hline Ser & 8.1 & $*$ & 9.0 & * & 0.6 & 0.35 & 2.5 & $*$ & 4.1 & * & 0.4 & 0.05 \\
\hline Thr & 8.5 & $*$ & 10.8 & * & 0.5 & 0.02 & 1.2 & $*$ & 0.9 & $*$ & 0.2 & 0.45 \\
\hline Trp & 6.7 & $*$ & 7.8 & * & 0.5 & 0.21 & & & & & & \\
\hline Tyr & 11.1 & $*$ & 12.0 & * & 1.1 & 0.60 & & & & & & \\
\hline Val & 29.0 & $*$ & 31.2 & * & 1.4 & 0.31 & 0.8 & $*$ & 1.8 & * & 0.2 & 0.03 \\
\hline TEAA $^{4}$ & 118.2 & * & 133.4 & * & 5.9 & 0.15 & 14.3 & * & 15.1 & * & 0.8 & 0.51 \\
\hline TNEAA $^{4}$ & 124.5 & * & 138.1 & * & 5.8 & 0.17 & 37.4 & $*$ & 44.5 & * & 4.6 & 0.34 \\
\hline TAA $^{4}$ & 242.7 & * & 271.5 & * & 11.2 & 0.15 & 51.7 & * & 59.6 & * & 5.4 & 0.35 \\
\hline
\end{tabular}

*, \#, Differs from zero at $P<0.001$ to 0.05 , or $P<0.11$ to 0.2 , (Trend), respectively.

${ }^{1}$ Probability of differing from zero.

${ }^{2} \mathrm{SE}$ of the model least square means.

${ }^{3}$ Probability of difference between treatments within pools (FAA or PBAA).

${ }^{4}$ Total essential AA (TEAA), total nonessential AA (TNEAA), and total AA (TAA).

fed SFC and PB-Val in cows fed SRC did not differ significantly from zero. The proportion of total PBAA to total FAA $(\mathrm{mg} / \mathrm{L})$ in the plasma of the mammary vein was 26.5 and $30.1 \%$ for cows fed SFC and SRC, respectively. These were greater than in the other three blood vessels (average 21.5\%). The ratio of total PBEAA to total EAA was only 12.4 and $14.7 \%$ for SFC and SRC, respectively.

\section{Fluxes of FAA and PBAA Between Plasma Pools}

Portal-drained visceral flux (PDVF). Fluxes of total EAA $(P<0.013)$ and total AA $(P<0.033)$ across the PDV were, on average, $56 \%$ greater for cows fed SFC than for cows fed SRC (Table 7). The PDVF of Gly, Hyp, Ile, Leu, Phe, Pro, Ser, Thr, Trp, and Val were greater $(P<0.015$ to 0.098$)$ in plasma of cows fed SFC, and PDVF of Ala, Arg, Lys, Met, and Tyr tended $(P<$ 0.11 to 0.17 ) to be so. The PDVF of PB-Asp, PB-Gly, PB-His, and PB-Ser were greater $(P<0.032$ to 0.10$)$ in cows fed SFC, and there was a tendency $(P<0.11$ to 0.17 ) for PDVF of PB-Orn, PB-Val, and PB-Pro to be greater in cows fed SFC.
Except for Gln, PDVF of all individual FAA in cows fed both diets differed significantly from zero. However, even though the PDVF of a substantial proportion of PBAA differed from zero, the similarity between diets regarding the differences from zero that were observed in the FAA pool, were maintained in the PBAA pool only for PB-Gly, PB-Hyp, PB-Ile, PB-Lys, PB-Orn, and PB-Thr. The PDVF of PB-Cit, PB-His, PB-Ser, and PBVal differed ( $P<0.008$ to 0.08 ), and PB-Leu tended ( $P$ $<0.12$ ) to differ from zero in the cows fed SFC diet, but not in cows fed SRC. To the contrary, the PDVF of PBAla, PB-Arg, PB-Asp, PB-Glu, and PB-Pro differed ( $P$ $<0.004$ to 0.09 ) from zero in cows fed SRC but not SFC. It is, therefore, suggested that dietary effect was apparently expressed not only on the differences in the PDV fluxes of FAA and PBAA but also on the profile of the PBAA pool.

Liver flux (uptake). The flux of more than half of the FAA in cows fed SFC diet differed from zero, but only a few differed from zero in the SRC diet (Table 8). Among the EAA, it is interesting to note that liver uptake of BCAA, Arg, Lys, and Trp in both diets was relatively small and did not differ from zero in both 
Table 4. Portal concentrations $(\mathrm{mg} / \mathrm{L})$ of free (FAA) and peptide bound amino acids (PBAA) in plasma of cows fed steam-flaked (SFC) or steam-rolled corn (SRC) to densities of 360 or $490 \mathrm{~g} / \mathrm{L}(\mathrm{n}=6)$.

\begin{tabular}{|c|c|c|c|c|c|c|c|c|c|c|c|c|}
\hline \multirow{3}{*}{$\begin{array}{l}\text { Pool } \\
\text { Diet } \\
\text { Amino acid }\end{array}$} & \multicolumn{6}{|c|}{ FAA } & \multicolumn{6}{|c|}{ PBAA } \\
\hline & \multirow{2}{*}{$\frac{\mathrm{SFC}}{\text { Mean }}$} & \multirow[b]{2}{*}{$P^{1}$} & \multicolumn{2}{|l|}{ SRC } & \multirow[b]{2}{*}{$\mathrm{SEM}^{2}$} & \multirow[b]{2}{*}{$P^{3}$} & \multirow{2}{*}{$\frac{\mathrm{SFC}}{\text { Mean }}$} & \multirow[b]{2}{*}{$P^{1}$} & \multirow{2}{*}{$\frac{\mathrm{SRC}}{\text { Mean }}$} & \multirow[b]{2}{*}{$P^{1}$} & \multirow[b]{2}{*}{$\mathrm{SEM}^{2}$} & \multirow[b]{2}{*}{$P^{3}$} \\
\hline & & & Mean & $P^{1}$ & & & & & & & & \\
\hline Ala & 28.4 & $*$ & 28.9 & $*$ & 1.9 & 0.84 & 3.5 & $*$ & 4.4 & $*$ & 1.0 & 0.55 \\
\hline Arg & 15.5 & * & 16.0 & * & 0.6 & 0.52 & 1.3 & $*$ & 1.3 & * & 0.2 & 0.92 \\
\hline Asn & 5.6 & $*$ & 5.4 & $*$ & 1.1 & 0.89 & & & & & & \\
\hline Asp & 2.3 & $*$ & 3.2 & $*$ & 0.5 & 0.32 & 3.6 & $*$ & 5.3 & $*$ & 0.8 & 0.24 \\
\hline Cit & 17.3 & $*$ & 18.4 & $*$ & 1.4 & 0.59 & 15.5 & $*$ & 16.3 & $*$ & 1.2 & 0.69 \\
\hline Gln & 17.6 & $*$ & 19.6 & $*$ & 1.8 & 0.47 & & & & & & \\
\hline Glu & 9.6 & $*$ & 9.3 & $*$ & 0.2 & 3.69 & 7.8 & $*$ & 6.9 & $*$ & 2.0 & 0.77 \\
\hline Gly & 22.4 & $*$ & 21.8 & $*$ & 1.8 & 0.82 & 39.0 & $*$ & 39.9 & $*$ & 2.2 & 0.78 \\
\hline His & 7.2 & $*$ & 7.4 & $*$ & 0.6 & 0.83 & 4.7 & $*$ & 4.6 & $*$ & 0.5 & 0.93 \\
\hline Нур & 2.4 & $*$ & 2.5 & $*$ & 0.2 & 0.79 & 0.8 & $*$ & 0.9 & $*$ & 0.1 & 0.63 \\
\hline Ile & 18.9 & * & 19.4 & * & 1.2 & 0.79 & 0.7 & $*$ & 0.5 & * & 0.2 & 0.63 \\
\hline Leu & 27.3 & $*$ & 27.8 & * & 1.7 & 0.85 & 2.3 & $*$ & 2.1 & * & 0.3 & 0.66 \\
\hline Lys & 11.9 & $*$ & 11.3 & $*$ & 0.9 & 0.64 & 3.2 & $*$ & 3.2 & * & 0.2 & 0.82 \\
\hline Met & 4.9 & $*$ & 4.5 & $*$ & 0.4 & 0.43 & 1.8 & $*$ & 1.6 & $*$ & 0.1 & 0.45 \\
\hline Orn & 4.7 & $*$ & 5.0 & $*$ & 0.1 & 0.15 & 3.0 & $*$ & 3.2 & $*$ & 0.2 & 0.43 \\
\hline Phe & 12.2 & $*$ & 12.6 & $*$ & 0.9 & 0.77 & 0.2 & & 0.4 & & 0.2 & 0.55 \\
\hline Pro & 13.5 & $*$ & 14.0 & $*$ & 0.6 & 0.58 & 1.9 & $*$ & 2.1 & $*$ & 0.2 & 0.63 \\
\hline Ser & 11.2 & $*$ & 11.4 & $*$ & 0.6 & 0.80 & 3.3 & $*$ & 3.2 & $*$ & 0.2 & 0.77 \\
\hline Thr & 10.9 & $*$ & 12.5 & $*$ & 0.6 & 0.13 & 1.8 & $*$ & 1.8 & $*$ & 0.2 & 0.89 \\
\hline Trp & 8.3 & $*$ & 8.4 & $*$ & 0.6 & 0.87 & & & & & & \\
\hline Tyr & 14.6 & $*$ & 14.6 & $*$ & 1.4 & 0.99 & & & & & & \\
\hline Val & 33.2 & $*$ & 33.5 & $*$ & 1.8 & 0.90 & 1.8 & $*$ & 1.9 & * & 0.1 & 0.79 \\
\hline TEAA $^{4}$ & 150.2 & $*$ & 153.3 & $*$ & 8.7 & 0.81 & 17.7 & $*$ & 17.3 & * & 1.1 & 0.78 \\
\hline TNEAA $^{4}$ & 149.6 & $*$ & 154.2 & * & 7.5 & 0.67 & 47.3 & $*$ & 49.5 & * & 4.9 & 0.76 \\
\hline $\mathrm{TAA}^{4}$ & 299.8 & $*$ & 307.5 & $*$ & 15.3 & 0.74 & 65.1 & $*$ & 66.8 & $*$ & 5.7 & 0.83 \\
\hline
\end{tabular}

*Differs from zero at $P<0.001$ to 0.05 , respectively.

${ }^{1}$ Probability of differing from zero.

${ }^{2}$ Standard error of the model least square means.

${ }^{3}$ Probability of difference between treatments within pools (FAA or PBAA).

${ }^{4}$ Total essential AA (TEAA), total nonessential AA (TNEAA), and total AA (TAA).

treatments and His in cows fed SRC. Of the NEAA, relatively large quantities of Ala, Gly, Cit, Pro, Tyr, and Ser were extracted $(P<0.01$ to 0.1$)$ by the liver of cows fed SFC. On the other hand, large $(P<0.01$ to 0.03) quantities of Glu, were delivered into the hepatic vein in cows fed both diets. Flux of Gln across the liver was not different from zero in cows fed SFC, whereas in cows fed SRC diets there was a tendency for it to be extracted by the liver. Nevertheless, in both types of corn, the FAA balance of Glu-Gln was positive, pointing at a supply by the liver of this FAA. The flux of many of the NEAA was observed to be significantly different from zero; however, differences observed between treatments were not significant.

Among the PBAA, Lys was, in both treatments, the only PBAA that was extracted by the liver in quantities differing from zero. The extraction of PB-Lys was 2.5 to 3 times greater than the extraction of Lys from the FAA pool. In cows fed SFC, PB-Lys was the only EAA that was extracted by the liver, whereas in cows fed SRC, there was liver uptake $(P<0.06$ to 0.10$)$ of PBVal, PB-Ile, PB-Lys, and total PB-EAA and a tendency
$(P<0.13$ to 0.19$)$ towards extraction of PB-Arg, PBHis, PB-Gly, PB-Orn, and total PBAA.

Liver extraction efficiency, \%. In several instances, in both types of corn, extraction ratios of FAA or PBAA differed $(P<0.001$ to 0.10$)$ from zero even though the efficiencies were relatively low (Table 9). Among the EAA, extraction of Met and Phe in both treatments, and for Thr in cows fed SFC, was relatively high. Of the NEAA in both treatments, high proportions of Ala, Gly, Ser, and Tyr in both treatments and Asn in cows fed SFC were extracted. Extraction in both treatments of total EAA averaged 2.9\% and was not significant, whereas extraction of NEAA was 5.7\% and, though small, differed from zero $(P<0.065)$. The extraction ratio of Glu was negative $(P<0.01$; i.e., it was delivered from the liver into the hepatic vein), whereas the extraction ratio was high and positive for PB-Glu, indicating that large amounts of PB-Glu were extracted by the liver in cows fed SFC $(P<0.06)$. The same was not true for cows fed SRC. It is worth mentioning that large quantities of PB-Glu were withdrawn from PDVF in cows fed SRC (Table 7), which might have caused a 
TAGARI ET AL.

Table 5. Hepatic vein concentrations ( $\mathrm{mg} / \mathrm{L}$ ) of free (FAA) and peptide bound amino acids (PBAA) in plasma of cows fed steam-flaked (SFC) or steam-rolled corn (SRC) at densities of 360 or $490 \mathrm{~g} / \mathrm{L}(\mathrm{n}=6)$.

\begin{tabular}{|c|c|c|c|c|c|c|c|c|c|c|c|c|}
\hline \multirow{3}{*}{$\begin{array}{l}\text { Pool } \\
\text { Diet } \\
\text { Amino acid }\end{array}$} & \multicolumn{6}{|c|}{ FAA } & \multicolumn{6}{|c|}{ PBAA } \\
\hline & \multirow{2}{*}{$\frac{\mathrm{SFC}}{\text { Mean }}$} & \multirow[b]{2}{*}{$P^{1}$} & \multicolumn{2}{|l|}{ SRC } & \multirow[b]{2}{*}{$\mathrm{SEM}^{2}$} & \multirow[b]{2}{*}{$P^{3}$} & \multirow{2}{*}{$\frac{\mathrm{SFC}}{\text { Mean }}$} & \multirow[b]{2}{*}{$P^{1}$} & \multirow{2}{*}{$\frac{\mathrm{SRC}}{\text { Mean }}$} & \multirow[b]{2}{*}{$P^{1}$} & \multirow[b]{2}{*}{$\mathrm{SEM}^{2}$} & \multirow[b]{2}{*}{$P^{3}$} \\
\hline & & & Mean & $P^{1}$ & & & & & & & & \\
\hline Ala & 23.4 & $*$ & 22.5 & * & 1.50 & 0.70 & 5.28 & \# & 2.36 & & 2.2 & 0.45 \\
\hline Arg & 13.8 & * & 14.3 & * & 0.42 & 0.44 & 1.56 & \# & 1.17 & & 0.6 & 0.68 \\
\hline Asn & 4.1 & $*$ & 4.3 & * & 1.74 & 0.96 & & & & & & \\
\hline Asp & 1.7 & $*$ & 3.0 & * & 0.26 & 0.07 & 2.57 & \# & 4.04 & $\wedge$ & 1.0 & 0.40 \\
\hline Cit & 15.3 & $*$ & 17.7 & * & 2.34 & 0.56 & 5.08 & & 16.1 & $\wedge$ & 4.1 & 0.20 \\
\hline Gln & 17.8 & $*$ & 15.6 & * & 2.55 & 0.61 & & & & & & \\
\hline Glu & 12.0 & $*$ & 12.5 & * & 0.40 & 0.44 & 4.44 & & 3.57 & & 3.4 & 0.24 \\
\hline Gly & 16.9 & $*$ & 18.2 & * & 2.33 & 0.72 & 32.2 & $*$ & 35.19 & $*$ & 3.5 & 0.61 \\
\hline His & 6.7 & $*$ & 6.7 & * & 0.65 & 0.97 & 4.15 & $*$ & 4.01 & $*$ & 0.8 & 0.91 \\
\hline Нyр & 2.0 & * & 2.1 & * & 0.26 & 0.84 & 1.14 & * & 0.99 & $\wedge$ & 0.3 & 0.78 \\
\hline Ile & 17.9 & * & 18.2 & * & 0.84 & 0.80 & 1.96 & & 0.11 & & 1.3 & 0.36 \\
\hline Leu & 26.4 & $*$ & 26.0 & * & 1.24 & 0.87 & 3.64 & $\wedge$ & 2.19 & & 1.5 & 0.57 \\
\hline Lys & 11.0 & $*$ & 10.9 & * & 1.24 & 0.87 & 2.68 & $\wedge$ & 2.52 & $*$ & 0.2 & 0.69 \\
\hline Met & 3.9 & $*$ & 4.0 & * & 0.21 & 0.86 & 1.49 & $\wedge$ & 1.68 & * & 0.2 & 0.51 \\
\hline Orn & 4.7 & * & 5.1 & * & 0.28 & 0.40 & 2.69 & $\wedge$ & 2.7 & $*$ & 0.1 & 0.92 \\
\hline Phe & 10.2 & $*$ & 10.7 & * & 0.80 & 0.83 & 0.63 & & 0.1 & & 0.5 & 0.55 \\
\hline Pro & 11.9 & * & 12.7 & $*$ & 0.27 & 0.17 & 2.96 & \# & 1.61 & & 1.4 & 0.55 \\
\hline Ser & 8.0 & $*$ & 8.8 & * & 0.21 & 0.12 & 2.72 & \# & 3.09 & * & 0.6 & 0.72 \\
\hline Thr & 9.1 & * & 11.1 & * & 0.11 & 0.06 & 2.51 & \# & 1.58 & $\wedge$ & 0.5 & 0.34 \\
\hline Trp & 7.8 & * & 7.2 & * & 0.43 & 0.43 & & & & & & \\
\hline Tyr & 12.5 & * & 12.3 & * & 1.15 & 0.91 & & & & & & \\
\hline Val & 31.7 & * & 31.5 & * & 1.90 & 0.95 & 5.21 & & 0.79 & & 3.1 & 0.42 \\
\hline TEAA $^{4}$ & 138.3 & * & 140.7 & * & 5.57 & 0.79 & 23.8 & $\wedge$ & 13.9 & \# & 6.4 & 0.38 \\
\hline TNEAA $^{4}$ & 130.3 & * & 134.9 & * & 4.50 & 0.56 & 40.1 & $\wedge$ & 37.4 & * & 5.5 & 0.76 \\
\hline TAA $^{4}$ & 268.6 & * & 275.4 & * & 8.10 & 0.61 & 63.9 & $\wedge$ & 51.4 & * & 10.6 & 0.49 \\
\hline
\end{tabular}

*, ^, \#, Differs from zero at $P<0.001$ to $0.05, P<0.05$ to 0.1 , or $P<0.11$ to 0.2 , (Trend), respectively.

${ }^{1}$ Probability of differing from zero.

${ }^{2}$ Standard error of the model least square means.

${ }^{3}$ Probability of difference between treatments within pools (FAA or PBAA).

${ }^{4}$ Total essential AA (TEAA), total nonessential AA (TNEAA), and total AA (TAA).

shortage in the liver and thus, be the reason for the very small quantities of PB-Glu withdrawn by the liver in that treatment.

Splanchnic flux. The magnitude of apparent differences between treatments in the splanchnic flux (Table 10) well reflect those that were observed for the PDVF. Although these differences were not found to be significant, a trend $(P<0.14$ to 0.19$)$ toward differences was observed for 7 individual AA, of which 5 were EAA. This applies as well to treatment differences for total EAA and total AA. The splanchnic flux of many more individual FAA differed from zero in cows fed SFC as compared to cows fed SRC. Splanchnic flux of 4 FAA, 2 essential (Lys and Arg) and 2 nonessential (Glu and Orn) differed from zero $(P<0.006$ to 0.095$)$ in both treatments. Among the PBAA, only the splanchnic fluxes of PB-Arg, PB-Asp, and PB-Val differed $(P<0.05$ to 0.07 ) from zero and only in cows fed SRC.

Mammary flux. Except for Trp and Met, MU of all other EFAA was numerically greater in SFC-fed cows and significantly $(P<0.01$ to 0.06$)$ so for 5 of the 10
(Table 11). This was reflected by a greater MU of total EAA in SFC-fed cows $(P<0.06)$.

The MU of several PBAA was also influenced by diet. Among the essential PBAA, MU of PB-Lys, PB-Leu, and PB-Thr was greater $(P<0.04$ to 0.09$)$ in cows fed $\mathrm{SFC}$, and the same trend $(P<0.16$ and 0.15 , respectively) was observed for PB-Met and PB-Ile. The MU of PB-Ser, to the contrary, was greater $(P<0.06)$ in cows fed SRC.

The importance of the contribution of the PBAA pool to the total amounts of individual AA extracted by the mammary gland was illustrated by the relative frequency with which MU differed from zero (Table 11). Indeed, in both treatments, MU of PB-Arg, PB-Lys, and PB-Met differed $(P<0.001$ to 0.07$)$ from zero. The MU of PB-Leu and PB-Thr differed $(P<0.004$ and 0.007 , respectively) from zero in cows fed SFC, whereas MU of PB-Ile differed $(P<0.07)$ from zero in the SRC-fed cows, thus pointing at a different dietary effect on the availability of certain AA for extraction from the PBAA pool as mentioned above. Of the PB-NEAA, only PB- 
Table 6. Mammary vein concentrations $(\mathrm{mg} / \mathrm{L})$ of free $(\mathrm{FAA})$ and peptide bound amino acids (PBAA) in plasma of cows fed steam-flaked (SFC) or steam-rolled corn (SRC) at densities of 360 or $490 \mathrm{~g} / \mathrm{L}(\mathrm{n}=6)$.

\begin{tabular}{|c|c|c|c|c|c|c|c|c|c|c|c|c|}
\hline \multirow{3}{*}{$\begin{array}{l}\text { Pool } \\
\text { Diet } \\
\text { Amino acid }\end{array}$} & \multicolumn{6}{|c|}{ FAA } & \multicolumn{6}{|c|}{ PBAA } \\
\hline & \multirow{2}{*}{$\frac{\mathrm{SFC}}{\text { Mean }}$} & \multirow[b]{2}{*}{$P^{1}$} & \multicolumn{2}{|l|}{ SRC } & \multirow[b]{2}{*}{$\mathrm{SEM}^{2}$} & \multirow[b]{2}{*}{$P^{3}$} & \multirow{2}{*}{$\frac{\text { SFC }}{\text { Mean }}$} & \multirow[b]{2}{*}{$P^{1}$} & \multirow{2}{*}{$\frac{\text { SRC }}{\text { Mean }}$} & \multirow[b]{2}{*}{$P^{1}$} & \multirow[b]{2}{*}{$\mathrm{SEM}^{2}$} & \multirow[b]{2}{*}{$P^{3}$} \\
\hline & & & Mean & $P^{1}$ & & & & & & & & \\
\hline Ala & 19.8 & * & 21.9 & $*$ & 1.1 & 0.24 & 2.3 & * & 2.84 & * & 0.23 & 0.19 \\
\hline Arg & 6.1 & $*$ & 7.9 & * & 0.6 & 0.09 & 0.8 & * & 1.20 & * & 0.12 & 0.06 \\
\hline Asn & 1.8 & $*$ & 1.7 & $\wedge$ & 0.7 & 0.91 & & & & & & \\
\hline Asp & 1.0 & $*$ & 1.9 & $*$ & 0.3 & 0.12 & 1.9 & $*$ & 2.96 & * & 0.52 & 0.21 \\
\hline Cit & 15.2 & $*$ & 17.5 & $*$ & 1.7 & 0.38 & 13.4 & $*$ & 15.32 & * & 1.63 & 0.46 \\
\hline Gln & 14.8 & $*$ & 15.8 & * & 1.4 & 0.61 & & & & & & \\
\hline Glu & 2.3 & * & 3.0 & * & 0.3 & 0.23 & 10.5 & * & 12.89 & * & 1.42 & 0.30 \\
\hline Gly & 19.3 & $*$ & 19.7 & * & 2.1 & 0.91 & 29.2 & $*$ & 33.54 & * & 1.90 & 0.19 \\
\hline His & 4.0 & $*$ & 4.8 & * & 0.5 & 0.30 & 4.1 & $*$ & 4.25 & * & 0.48 & 0.83 \\
\hline Нур & 2.2 & * & 2.4 & * & 0.2 & 0.59 & 1.0 & * & 1.14 & * & 0.10 & 0.27 \\
\hline Ile & 9.3 & * & 11.0 & * & 0.4 & 0.04 & 0.2 & & 0.61 & & 0.31 & 0.39 \\
\hline Leu & 11.6 & * & 14.1 & * & 0.3 & 0.01 & 1.1 & * & 1.78 & * & 0.24 & 0.12 \\
\hline Lys & 3.3 & $*$ & 3.9 & * & 0.3 & 0.18 & 1.0 & $*$ & 1.48 & * & 0.20 & 0.19 \\
\hline Met & 1.1 & * & 1.1 & * & 0.4 & 0.97 & 0.6 & $*$ & 0.85 & * & 0.19 & 0.35 \\
\hline Orn & 2.3 & $*$ & 2.8 & * & 0.2 & 0.07 & 1.8 & $*$ & 2.34 & * & 0.17 & 0.09 \\
\hline Phe & 4.4 & $*$ & 5.8 & * & 0.5 & 0.12 & 0.2 & & 0.49 & * & 0.19 & 0.32 \\
\hline Pro & 8.9 & $*$ & 10.3 & * & 0.4 & 0.08 & 1.6 & * & 1.73 & * & 0.15 & 0.44 \\
\hline Ser & 5.1 & * & 5.6 & * & 0.7 & 0.64 & 1.8 & $*$ & 2.28 & * & 0.17 & 0.10 \\
\hline Thr & 5.5 & * & 7.6 & * & 0.5 & 0.03 & 0.5 & $*$ & 1.00 & * & 0.12 & 0.04 \\
\hline Trp & 5.8 & * & 6.5 & * & 0.4 & 0.30 & & & & & & \\
\hline Tyr & 6.9 & $*$ & 8.2 & * & 0.8 & 0.30 & & & & & & \\
\hline Val & 22.0 & * & 24.7 & * & 0.6 & 0.04 & 0.7 & \# & 1.17 & * & 0.34 & 0.36 \\
\hline TEAA $^{4}$ & 73.0 & * & 87.3 & $*$ & 2.9 & 0.03 & 9.1 & $*$ & 12.84 & * & 1.05 & 0.07 \\
\hline TNEAA $^{4}$ & 99.6 & * & 110.8 & * & 7.0 & 0.32 & 36.6 & * & 44.38 & * & 3.50 & 0.19 \\
\hline $\mathrm{TAA}^{4}$ & 172.5 & $*$ & 190.1 & $*$ & 9.6 & 0.13 & 45.7 & $*$ & 57.20 & $*$ & 4.46 & 0.14 \\
\hline
\end{tabular}

*, ^, \#, Differs from zero at $P<0.001$ to $0.05, P<0.05$ to 0.1 , or $P<0.11$ to 0.2 , (Trend), respectively.

${ }^{1}$ Probability of differing from zero.

${ }^{2}$ Standard error of the model least square means.

${ }^{3}$ Probability of difference between treatments within pools (FAA or PBAA).

${ }^{4}$ Total essential AA (TEAA), total nonessential AA (TNEAA), and total AA (TAA).

Ser was extracted by the mammary gland in amounts differing $(P<0.009$ to 0.06$)$ from zero in both treatments. The MU of PB-Asp differed from zero in cows fed SFC only.

Extraction of PBAA, as a percentage of FAA extraction, varied from $67 \%$ for PB-Met in cows fed SFC, down to $13.5 \%$ for PB-Arg in cows fed SRC. The MU of PBAA represents a substantial addition to the extraction from the FAA pool. Of all PB-EAA, PB-Lys, and PB-Met were extracted in the largest quantities, and the difference between the treatments regarding their MU and secretion in milk was always significant.

Secretion of AA in milk. Secretion of individual AA in milk was generally greater in cows fed SFC compared with cows fed SRC (Table 11). Quantities of Ala and Lys secreted in milk were greater $(P<0.08$ and 0.09 , respectively) and all other AA, except Thr, tended $(P<$ 0.11 to 0.18 ) to be greater in cows fed SFC. Differences between treatments correspond well with the greater $(P<0.069)$ amounts of total CP secreted in milk of cows fed SFC (Table 2).
Mammary extraction efficiency. The MEE of Tyr was greater $(P<0.067)$ in cows fed SFC and tended $(P$ $<0.17)$ to be so for His and Phe (Table 12). The MEE of all FAA, except for Gln, Gly, Met, and Trp, was numerically greater when the cows were fed the SFC diet. The MEE differed $(P<0.001$ to 0.10$)$ from zero in both treatments for the majority of FAA. The MEE for PBAA differed $(P<0.001$ to 0.063 ) from zero for half (PB-Arg, PB-Asp, PB-Leu, PB-Lys, PB-Met, PB-Orn, PB-Phe, PB-Ser, and PB-Thr) of the AA quantified in cows fed SFC. Fewer differences from zero (PB-Arg, PB-Lys, PBMet, PB-Orn, and PB-Ser) were noted when SRC was fed. There were more instances of differences from zero in the case of EAA compared with NEAA. The MEE was greater $(P<0.07,0.08)$ for PB-Cit and PB-Lys and tended $(P<0.19)$ to be greater for PB-Met and PB-Pro and total EAA $(P<0.15)$ when SFC was fed.

\section{DISCUSSION}

Milk and milk protein yields on sampling day were greater in cows fed SFC compared with SRC, which 
TAGARI ET AL.

Table 7. Portal drained viscera flux, g/ $12 \mathrm{~h}$, of free (FAA) and peptide bound amino acids (PBAA) in plasma of cows fed steam-flaked (SFC) or steam-rolled corn (SRC) to densities of 360 or $490 \mathrm{~g} / \mathrm{L}(\mathrm{n}=6)$.

\begin{tabular}{|c|c|c|c|c|c|c|c|c|c|c|c|c|}
\hline \multirow{3}{*}{$\begin{array}{l}\text { Pool } \\
\text { Diet } \\
\text { Amino acid }\end{array}$} & \multicolumn{6}{|c|}{ FAA } & \multicolumn{6}{|c|}{ PBAA } \\
\hline & \multirow{2}{*}{$\frac{\mathrm{SFC}}{\text { Mean }}$} & \multirow[b]{2}{*}{$P^{1}$} & \multicolumn{2}{|l|}{ SRC } & \multirow[b]{2}{*}{$\mathrm{SEM}^{2}$} & \multirow[b]{2}{*}{$P^{3}$} & \multirow{2}{*}{$\frac{\text { SFC }}{\text { Mean }}$} & \multirow[b]{2}{*}{$P^{1}$} & \multirow{2}{*}{$\frac{\text { SRC }}{\text { Mean }}$} & \multirow[b]{2}{*}{$P^{1}$} & \multirow[b]{2}{*}{$\mathrm{SEM}^{2}$} & \multirow[b]{2}{*}{$P^{3}$} \\
\hline & & & Mean & $P^{1}$ & & & & & & & & \\
\hline Ala & 102.9 & $*$ & 78.2 & * & 8.8 & 0.11 & 7.3 & & 16.9 & $\wedge$ & 7.6 & 0.42 \\
\hline Arg & 67.1 & * & 46.5 & $*$ & 8.6 & 0.16 & -5.2 & & -11.6 & * & 3.6 & 0.28 \\
\hline Asn & 33.3 & * & 33.1 & $*$ & 4.6 & 0.93 & & & & & & \\
\hline Asp & 9.3 & * & 1.5 & * & 4.6 & 0.30 & 1.9 & & 41.2 & * & 12.5 & 0.10 \\
\hline Cit & 24.6 & * & 9.3 & $*$ & 8.1 & 0.25 & -24.2 & $\wedge$ & -18.6 & \# & 10.2 & 0.72 \\
\hline Gln & 9.0 & & -6.9 & & 23.2 & 0.65 & & & & & & \\
\hline Glu & 27.6 & * & 18.8 & * & 7.9 & 0.48 & -32.8 & & -79.8 & $\wedge$ & 48.6 & 0.53 \\
\hline Gly & 56.3 & * & 24.6 & $*$ & 4.6 & 0.01 & 187.9 & $*$ & 130.5 & * & 19.0 & 0.10 \\
\hline His & 21.0 & * & 14.6 & * & 5.3 & 0.44 & 12.4 & * & 1.3 & & 2.4 & 0.03 \\
\hline Нур & 4.3 & $*$ & 2.8 & * & 0.4 & 0.06 & -1.7 & $*$ & -2.2 & $\wedge$ & 0.8 & 0.66 \\
\hline Ile & 64.2 & * & 40.9 & * & 6.9 & 0.08 & 6.2 & $\wedge$ & 10.5 & * & 3.1 & 0.37 \\
\hline Leu & 103.8 & * & 66.0 & * & 6.6 & 0.02 & 10.4 & \# & 7.6 & & 8.6 & 0.83 \\
\hline Lys & 66.4 & $*$ & 45.6 & $*$ & 7.6 & 0.12 & 11.6 & $\wedge$ & 10.8 & * & 4.8 & 0.91 \\
\hline Met & 36.2 & $*$ & 21.1 & $*$ & 6.5 & 0.17 & -2.3 & & -0.1 & & 5.3 & 0.78 \\
\hline Orn & 16.6 & $*$ & 9.7 & * & 5.5 & 0.43 & 11.1 & $*$ & 6.1 & $\wedge$ & 1.8 & 0.11 \\
\hline Phe & 67.0 & $*$ & 48.9 & $*$ & 4.4 & 0.04 & -4.3 & & 1.3 & & 4.7 & 0.46 \\
\hline Pro & 45.5 & * & 25.1 & * & 4.8 & 0.04 & 4.2 & & 15.3 & $*$ & 4.7 & 0.17 \\
\hline Ser & 55.3 & $*$ & 45.2 & $*$ & 2.6 & 0.05 & 14.2 & $*$ & -17.3 & $\#$ & 7.7 & 0.04 \\
\hline Thr & 44.4 & $*$ & 31.2 & $*$ & 4.0 & 0.08 & 11.7 & $\wedge$ & 16.1 & $\wedge$ & 5.9 & 0.62 \\
\hline Trp & 29.1 & * & 10.3 & * & 6.2 & 0.10 & & & & & & \\
\hline Tyr & 62.0 & $*$ & 48.2 & * & 5.2 & 0.13 & & & & & & \\
\hline Val & 71.9 & * & 41.4 & * & 5.0 & 0.05 & 19.5 & $*$ & 3.9 & & 5.7 & 0.12 \\
\hline TEAA $^{4}$ & 571.2 & * & 366.4 & * & 51.4 & 0.01 & 59.8 & $*$ & 39.8 & $*$ & 19.8 & 0.52 \\
\hline TEAA $^{4,5}$ & & & & & & & 69.3 & $*$ & 51.5 & * & 17.2 & 0.33 \\
\hline TNEAA $^{4}$ & 446.6 & $*$ & 289.7 & $*$ & 37.3 & 0.04 & 167.9 & $*$ & 92.0 & \# & 45.3 & 0.30 \\
\hline $\mathrm{TAA}^{4}$ & 1017.7 & $*$ & 656.1 & $*$ & 80.3 & 0.03 & 227.7 & $*$ & 131.8 & $\#$ & 62.1 & 0.33 \\
\hline & from & & $<0.0$ & to & $5 P$ & & $P$ & 0.11 & ? & & esne & \\
\hline${ }^{1}$ Probabi & diffe & & zero. & & & & & & & & & \\
\hline${ }^{2}$ Standar & or of $t$ & $\mathrm{mc}$ & least & ua & neans & & & & & & & \\
\hline${ }^{3}$ Probabil & f differ & ce & ween $t$ & atn & ts wit & poo & AA o & $\mathrm{BA}$ & & & & \\
\hline $\begin{array}{l}{ }^{4} \text { Total es } \\
{ }^{5} \text { Positive }\end{array}$ & al AA & & total $\mathrm{r}$ & & & & & & & & & \\
\hline
\end{tabular}

agrees with results of earlier studies (Theurer et al., 1999; Delgado-Alorduy et al., 2002b). They reported increases in milk, $3 \% \mathrm{FCM}$, and milk protein of $6,3.5$, and $8 \%$, respectively, in cows fed SFC compared with cows fed SRC.

Whereas $\mathrm{N}$ and calculated energy intakes were similar between treatments (Table 2), PDVF of FAA and PBAA were approximately $56 \%$ greater in cows fed SFC. Also, considering that protein sources were similar for both diets, it is reasonable to believe that the substantial increase in the PDVF of FAA and PBAA originates from a greater intestinal flow and absorption of microbial protein in cows fed SFC caused by the steam flaking of the corn grain. Al-Dehneh et al. (1997) reported that endogenous urea contributed 19.1 and $37.5 \%$ of $\mathrm{N}$ in duodenal digesta and flow, respectively, in diets containing $57 \%$ corn grain or $60 \%$ concentrate compared with 7.4 and $12.7 \%$, respectively, in diets containing $30 \%$ corn grain or $40 \%$ concentrate. This suggests that additional dietary starch will enhance urea recycling into the rumen. The effect of steam flak- ing may be considered as adding dietary starch. Indeed, Oliviera et al. (1995) reported that steam flaking sorghum resulted in more starch digestion in the rumen compared with dry rolling sorghum. Further, Plascenica and Zinn (1996) compared feeding dry-rolled corn (39\% of the diet) with feeding corn grain steam-flaked at densities of 390,320 , or $280 \mathrm{~g} / \mathrm{L}$ and observed an increase in ruminal starch digestion accompanied by an average increase of $26.6 \%$ in microbial $\mathrm{N}$ flow into the duodenum and an increase in the microbial $\mathrm{N}$ efficiency. A greater recycling of urea into the rumen, accompanied by a greater duodenal flow of total and bacterial N, was observed when high-grain compared with high-forage diets, were fed to lactating cows (Al-Dehneh et al., 1997). The PDV recycling of urea was about 2.5 times greater in steam-flaked corn or sorghum diets compared with dry-rolled or steam-rolled sorghum or corn diets, respectively (Delgado-Alorduy et al., 2002a, $2002 \mathrm{~b}$ ). We, therefore, suggest that the larger PDVF of FAA and PBAA in the SFC diet may be the result of the SFC enhancing urea recycling and microbial synthesis. 
Table 8. Liver flux of free (FAA) and peptide bound amino acids (PBAA), g/12 h, in plasma of cows fed corn grain, steam-flaked (SFC) or steam-rolled (SRC) to density of 360 or $490 \mathrm{~g} / \mathrm{L}(\mathrm{n}=4)$.

\begin{tabular}{|c|c|c|c|c|c|c|c|c|c|c|c|c|}
\hline \multirow{3}{*}{$\begin{array}{l}\text { Pool } \\
\text { Diet } \\
\text { Amino acid }\end{array}$} & \multicolumn{6}{|c|}{ FAA } & \multicolumn{6}{|c|}{ PBAA } \\
\hline & \multirow{2}{*}{$\frac{\mathrm{SFC}}{\text { Mean }}$} & \multirow[b]{2}{*}{$P^{1}$} & \multirow{2}{*}{$\frac{\mathrm{SRC}}{\text { Mean }}$} & \multirow[b]{2}{*}{$P^{1}$} & \multirow[b]{2}{*}{$\mathrm{SEM}^{2}$} & \multirow[b]{2}{*}{$P^{3}$} & \multirow{2}{*}{$\frac{\text { SFC }}{\text { Mean }}$} & \multirow[b]{2}{*}{$P^{1}$} & \multirow{2}{*}{$\frac{\mathrm{SRC}}{\text { Mean }}$} & \multirow[b]{2}{*}{$P^{1}$} & \multirow[b]{2}{*}{$\mathrm{SEM}^{2}$} & \multirow[b]{2}{*}{$P^{3}$} \\
\hline & & & & & & & & & & & & \\
\hline Ala & -55.7 & $*$ & -73.2 & * & 20.3 & & 66.9 & & -44.7 & & 78.5 & 0.42 \\
\hline Arg & -9.2 & & -10.8 & & 18.9 & & 6.5 & & -6.0 & \# & 15.8 & 0.63 \\
\hline Asn & -14.8 & $\wedge$ & -7.9 & & 2.7 & & & & & & & \\
\hline Asp & -1.7 & & -4.6 & & 4.8 & & -23.8 & & -2.7 & & 2.7 & 0.03 \\
\hline Cit & -22.1 & $\wedge$ & 1.2 & & 11.3 & & 252.1 & & -8.2 & & 167.9 & 0.38 \\
\hline Gln & 18.9 & & -41.1 & \# & 21.1 & \# & & & & & & \\
\hline Glu & 60.7 & $*$ & 68.1 & * & 15.8 & & -228.6 & & -81.5 & & 59.9 & 0.22 \\
\hline Gly & -49.3 & $*$ & -54.1 & \# & 15.3 & & -117.0 & & -64.8 & \# & 35.0 & 0.40 \\
\hline His & -6.6 & $\wedge$ & -6.6 & & 3.8 & & -18.0 & & -10.3 & \# & 6.0 & 0.46 \\
\hline Нур & -3.1 & * & -6.0 & $\wedge$ & 2.5 & & 8.1 & & 0.5 & & 5.8 & 0.45 \\
\hline Ile & -0.7 & & -4.5 & & 20.5 & & 39.1 & & -15.7 & $\wedge$ & 31.3 & 0.34 \\
\hline Leu & -2.4 & & -17.0 & & 28.2 & & 35.7 & & 6.9 & & 42.6 & 0.68 \\
\hline Lys & -3.9 & & -4.1 & & 15.8 & & -13.3 & $*$ & -10.7 & $\wedge$ & 4.6 & 0.73 \\
\hline Met & -12.5 & $*$ & -10.4 & & 5.3 & & -5.9 & & -0.2 & & 5.5 & 0.53 \\
\hline Orn & 4.6 & & 4.7 & & 5.7 & & -2.7 & & -3.7 & \# & 1.4 & 0.66 \\
\hline Phe & -22.8 & $*$ & -34.1 & $\wedge$ & 12.5 & & 12.7 & & -4.1 & & 15.7 & 0.53 \\
\hline Pro & -18.0 & * & 21.1 & & 13.1 & & 25.6 & & -11.5 & & 28.3 & 0.45 \\
\hline Ser & -36.2 & $*$ & -39.0 & $\wedge$ & 10.3 & & -12.1 & & -6.9 & & 12.7 & 0.80 \\
\hline Thr & -15.8 & $*$ & -15.8 & & 11.7 & & 14.3 & & -5.1 & & 14.5 & 0.45 \\
\hline Trp & -5.9 & & -16.0 & & 7.7 & & & & & & & \\
\hline Tyr & -25.6 & * & -34.0 & & 16.5 & & & & & & & \\
\hline Val & -1.2 & & -7.2 & & 20.5 & & 91.7 & & -29.8 & $\wedge$ & 87.3 & 0.42 \\
\hline TEAA $^{4}$ & -81.0 & & -126.6 & & 142.2 & & 162.9 & & -74.9 & $\wedge$ & 194.1 & 0.48 \\
\hline TNEAA $^{4}$ & -142.1 & * & -207.0 & & 97.7 & & -31.4 & & -223.5 & \# & 198.7 & 0.57 \\
\hline $\mathrm{TAA}^{4}$ & -223.1 & $\wedge$ & -333.6 & & 237.7 & & 131.4 & & -298.4 & \# & 392.9 & 0.52 \\
\hline
\end{tabular}

*, ^, \#, Differs from zero at $P<0.001$ to $0.05, P<0.05$ to 0.1 , or $P<0.11$ to 0.2 , (Trend), respectively.

${ }^{1}$ Probability of differing from zero.

${ }^{2}$ Standard error of the model least square means.

${ }^{3}$ Probability of difference between treatments within pools (FAA or PBAA).

${ }^{4}$ Total essential AA (TEAA), total nonessential AA (TNEAA), and total AA (TAA).

The PDVF of essential FAA and PBAA was approximately $50 \%$ greater in SFC- than in SRC-fed cows but was not uniform across all EAA. Differences ranged from highs of $74 \pm 14 \%$ for FAA-Val and $101 \pm 15 \%$ for PB-Val to lows of $37 \pm 22 \%$ for FAA-Phe and $29 \pm 27 \%$ for PB-Phe.

In light of the considerable increase in PDVF of FAA and PBAA observed in cows fed SFC, one would expect that this advantage might be expressed proportionally in the performance of those cows (i.e., in milk and milk protein yields). The more limited advantage observed in cows fed SFC may have arisen for several reasons. One possibility is that there was an imbalance in the biological value of the mixture of AA from the PDV caused by shortage of some AA, as mentioned above with respect to Phe. Another could be that the cows were in midlactation during the experimental period. It has been shown that, at midlactation, cows start to divert large quantities of absorbed nutrients for rebuilding body tissues (Flatt et al., 1969). Further, Moe and Tyrrell (1979) reported that cows at midlactation may divert as much as 59\% of absorbed energy to body tissues when fed quasi-concentrate diets and up to $67 \%$ when corn grain-based diets are fed. Even though the PDVF of FAA and PBAA was about $55 \%$ higher in SFC cows, the increase in Phe (FAA + PBAA) was only $25 \%$. Thus, in comparison to the average increase of $56 \%$, Phe was limiting in PDVF of cows fed SFC compared with DRC. If according to Moe and Tyrrel (1979), at midlactation, $67 \%$ of the absorbed nutrients are diverted to body building and only $33 \%$ to milk yield, then only $4.125 \mathrm{~g} / 12 \mathrm{~h}(12.5 \times 33 \%)$ of the increase in PDVF in SFC cows over dry-rolled corn will be diverted to milk production. According to NRC (2001), the efficiency of conversion of absorbed AA into milk protein is 0.67. That would mean $4.125 \times 0.67=2.674 \mathrm{~g} / 12 \mathrm{~h}$ of Phe available for milk CP synthesis. Therefore, with Phe comprising $4.7 \%$ of milk CP, the absorbed Phe would enable increased production of $58.8 \mathrm{~g}$ of milk CP in SFC cows compared with SRC cows. The actual increase in total milk AA output was $24 \mathrm{~g} / 12 \mathrm{~h}$ for the milk AA and $40 \mathrm{~g} / 12 \mathrm{~h}$ of milk CP as determined by DHI (Table 2).

The role of $P B A A$. It is well accepted that, unless specific marking compounds are used, it is impossible 
TAGARI ET AL.

Table 9. Liver extraction efficiency (LEE \%), of free (FAA) and peptide bound amino acids (PBAA) in plasma of cows fed corn grain steam-flaked (SFC) or steam-rolled (SRC) to density of 360 or $490 \mathrm{~g} / \mathrm{L}(\mathrm{n}=4)$.

\begin{tabular}{|c|c|c|c|c|c|c|c|c|c|c|c|c|}
\hline \multirow{3}{*}{$\begin{array}{l}\text { Pool } \\
\text { Diet } \\
\text { Amino acid }\end{array}$} & \multicolumn{6}{|c|}{ FAA } & \multicolumn{6}{|c|}{ PBAA } \\
\hline & SFC & & SRC & & & & $\mathrm{SFC}$ & & SRC & & & \\
\hline & Mean & $P^{1}$ & Mean & $P^{1}$ & SEM $^{2}$ & $P^{3}$ & Mean & $P^{1}$ & Mean & $P^{1}$ & $\mathrm{SEM}^{2}$ & $P^{3}$ \\
\hline $\mathrm{Ala}$ & 11.0 & $*$ & 12.8 & $*$ & 2.5 & 0.67 & -121.2 & & 37.3 & $\wedge$ & 112.9 & 0.42 \\
\hline Arg & 3.3 & & 2.5 & & 6.4 & 0.93 & -9.3 & & 17.8 & \# & 43.2 & 0.70 \\
\hline Asn & 15.7 & $*$ & -0.7 & & 2.1 & 0.06 & & & & & & \\
\hline Asp & 3.4 & & 6.5 & & 7.7 & 0.80 & 24.5 & & -17.2 & & 8.53 & 0.07 \\
\hline Cit & 6.1 & $*$ & 0.3 & & 2.7 & 0.26 & 56.3 & & -1.8 & & 36.1 & 0.37 \\
\hline Gln & -5.0 & & 12.3 & \# & 6.4 & 0.19 & & & & & & \\
\hline Glu & -32.1 & $*$ & -37.8 & $*$ & 8.7 & 0.69 & 359.9 & $\wedge$ & -4.7 & & 67.2 & 0.06 \\
\hline Gly & 12.7 & $*$ & 11.4 & $\wedge$ & 4.3 & 0.85 & 14.0 & \# & 7.8 & \# & 4.95 & 0.47 \\
\hline His & 4.0 & \# & 3.8 & & 1.6 & 0.95 & 17.8 & & 7.3 & \# & 6.96 & 0.40 \\
\hline Нур & 8.2 & $\wedge$ & 11.4 & * & 5.5 & 0.71 & -36.1 & & -7.0 & & 21.1 & 0.43 \\
\hline Ile & 0.6 & & -0.6 & & 5.4 & 0.89 & -299.8 & & 149.9 & $\wedge$ & 248.9 & 0.32 \\
\hline Leu & 0.8 & & 1.1 & & 4.7 & 0.96 & -73.3 & & -19.9 & & 90.3 & 0.71 \\
\hline Lys & 2.2 & & -0.5 & & 6.8 & 0.81 & 20.0 & $*$ & 17.3 & & 7.04 & 0.81 \\
\hline Met & 13.8 & * & 9.5 & \# & 5.2 & 0.61 & 7.1 & & -5.0 & & 20.4 & 0.71 \\
\hline Orn & -5.2 & & -4.4 & & 5.9 & 0.93 & 5.6 & & 7.0 & $\wedge$ & 2.78 & 0.76 \\
\hline Phe & 10.4 & $*$ & 12.0 & $*$ & 3.8 & 0.79 & 1293.0 & & 144.4 & $*$ & 829.9 & 0.43 \\
\hline Pro & 7.1 & $*$ & 5.9 & & 4.4 & 0.86 & -36.5 & & 25.2 & & 51.3 & 0.48 \\
\hline Ser & 18.9 & * & 16.1 & * & 4.7 & 0.71 & 19.1 & & 2.6 & & 20.18 & 0.62 \\
\hline Thr & 8.7 & * & 4.8 & & 4.8 & 0.62 & -28.0 & & 10.5 & & 31.86 & 0.48 \\
\hline Trp & 3.7 & $\wedge$ & 7.9 & \# & 3.2 & 0.44 & & & & & & \\
\hline Tyr & 9.3 & * & 9.5 & \# & 4.4 & 0.98 & & & & & & \\
\hline Val & 0.5 & & 0.4 & & 2.7 & 0.98 & -229.6 & & 55.1 & * & 202.9 & 0.42 \\
\hline TEAA $^{4}$ & 3.1 & & 2.7 & & 4.3 & 0.95 & -40.1 & & 18.0 & $*$ & 47.96 & 0.48 \\
\hline TNEAA $^{4}$ & 5.3 & $*$ & 6.1 & \# & 2.8 & 0.85 & 4.1 & & 17.1 & \# & 19.75 & 0.68 \\
\hline $\mathrm{TAA}^{4}$ & 4.2 & $\wedge$ & 4.5 & & 3.4 & 0.95 & -10.1 & & 17.4 & \# & 29.1 & 0.57 \\
\hline
\end{tabular}

*, ^, \#, Differs from zero at $P<0.001$ to $0.05, P<0.05$ to 0.1 , or $P<0.11$ to 0.2 , (Trend), respectively.

${ }^{1}$ Probability of differing from zero.

${ }^{2}$ Standard error of the model least square means.

${ }^{3}$ Probability of difference between treatments within pools (FAA or PBAA).

${ }^{4}$ Total essential AA (TEAA), total nonessential AA (TNEAA), and total AA (TAA).

to decide whether the addition or the removal of FAA or PBAA from their blood pools is the result of absorption from, or secretion into the GIT lumen, or of the metabolism by the GIT (Remond et al., 2000). Koeln et al. (1993) observed a greater PDVF of PBAA in fed vs. fasted calves and attributed this flux, in part at least, to absorption of peptides from the GIT lumen. Remond et al. (2000) injected casein hydrolysate into the rumen, in addition to a control meal, and observed an increase in PDVF of PB-Ile, PB-Leu, and PB-Pro and in total PB-EAA. These authors concluded that this increase in the flux of PBAA could be attributed, in part at least, to absorption of peptides from the GIT. In the present study, the large increase in PDVF of FAA in cows fed SFC compared with cows fed SRC was accompanied by an increase in the PDVF of 4 PBAA and a trend for an increase for another 2. This may indicate that these increases might be attributable to dietary and not metabolic effects.

It has been recently suggested that the PBAA pool in blood may serve as a reserve pool of AA. Koeln et al. (1993) observed, in both unfed and fed calves, negative
PDVF of Gln and Glu either as FAA or as PBAA. Lapierre et al. (2000) studied the effect of level of feed intake on splanchnic metabolism in steers and also reported a negative flux of Gln but observed a positive flux of Glu at all 3 levels of feed intake. In the present study with lactating dairy cows, the results regarding PDVF of Gln were not unequivocal, but those of Glu differed from zero (Table 7) and were lower (NS) in cows fed SRC. However, the peptide pool exhibited a different pattern. The PDVF of PB-Glu was negative and the removal of PB-Glu by PDV tissues was greater than the positive PDVF of Glu in the FAA pool in cows fed SRC. It is also worth mentioning that the negative flux of PB-Glu differed from zero and was greater in cows fed SRC compared with SFC-fed cows, which seems in accordance with the smaller flux of FAA Glu in SRCfed cows. Tagari and Bergman (1978) reported that only $2.87 \%$ of the ${ }^{14} \mathrm{C}$-Glu that was infused in the abomasum of sheep appeared in the portal vein as ${ }^{14} \mathrm{C}$-Glu. In addition, $1.18 \%$ of that infused ${ }^{14} \mathrm{C}$-Glu appeared as ${ }^{14} \mathrm{C}$ Gln. They reported the portal appearance of nonlabeled Glu bo be 6.3 and $-9.7 \%$ for high- and low-protein diets, 
Table 10. Splanchnic flux of free (FAA) and peptide bound amino acids (PBAA), g/12 h, in plasma of cows fed corn grain, steam-flaked (SFC) or steam-rolled (SRC) to density of 360 or $490 \mathrm{~g} / \mathrm{L}(\mathrm{n}=4)$.

\begin{tabular}{|c|c|c|c|c|c|c|c|c|c|c|c|c|}
\hline \multirow{3}{*}{$\begin{array}{l}\text { Pool } \\
\text { Diet } \\
\text { Amino acid }\end{array}$} & \multicolumn{6}{|c|}{ FAA } & \multicolumn{6}{|c|}{ PBAA } \\
\hline & \multirow{2}{*}{$\frac{\mathrm{SFC}}{\text { Mean }}$} & \multirow[b]{2}{*}{$P^{1}$} & \multirow{2}{*}{$\frac{\text { SRC }}{\text { Mean }}$} & \multirow[b]{2}{*}{$P^{1}$} & \multirow[b]{2}{*}{$\mathrm{SEM}^{2}$} & \multirow[b]{2}{*}{$P^{3}$} & \multirow{2}{*}{$\frac{\mathrm{SFC}}{\text { Mean }}$} & \multirow[b]{2}{*}{$P^{1}$} & \multirow{2}{*}{$\frac{\text { SRC }}{\text { Mean }}$} & \multirow[b]{2}{*}{$P^{1}$} & \multirow[b]{2}{*}{$\mathrm{SEM}^{2}$} & \multirow[b]{2}{*}{$P^{3}$} \\
\hline & & & & & & & & & & & & \\
\hline Ala & 48.8 & * & -5.8 & & 16.6 & 0.14 & 71.4 & & -22.9 & & 68.1 & 0.43 \\
\hline Arg & 59.2 & * & 25.7 & $\wedge$ & 14.9 & 0.25 & 4.8 & & -19.5 & $\wedge$ & 13.4 & 0.32 \\
\hline Asn & 13.0 & $\wedge$ & 21.5 & \# & 9.7 & 0.60 & & & & & & \\
\hline Asp & 8.3 & * & -6.2 & & 5.3 & 0.19 & -11.4 & & 23.9 & * & 6.8 & 0.07 \\
\hline Cit & 4.5 & & 6.9 & & 2.8 & 0.60 & 228.7 & & -13.5 & & 166.5 & 0.41 \\
\hline Gln & 35.2 & & -31.4 & \# & 34.7 & 0.30 & & & & & & \\
\hline Glu & 89.5 & * & 83.1 & * & 18.7 & 0.80 & -272.9 & & -176.5 & $\wedge$ & 119.2 & 0.62 \\
\hline Gly & 4.4 & & -29.5 & & 20.0 & 0.40 & 77.2 & & 36.3 & & 33.2 & 0.47 \\
\hline His & 16.5 & * & 6.3 & & 4.1 & 0.21 & -4.1 & & -10.7 & & 5.98 & 0.51 \\
\hline Нур & 0.6 & & -3.6 & & 2.4 & 0.33 & 7.4 & & -1.3 & & 6.5 & 0.45 \\
\hline Ile & 68.8 & * & 30.9 & \# & 13.9 & 0.19 & 43.7 & & -2.4 & & 32.3 & 0.42 \\
\hline Leu & 102.5 & * & 38.5 & & 23.3 & 0.19 & 51.4 & & 4.5 & & 41.2 & 0.50 \\
\hline Lys & 63.4 & * & 39.3 & $*$ & 11.8 & 0.29 & 3.0 & & -1.8 & & 5.7 & 0.60 \\
\hline Met & 27.1 & $\wedge$ & 10.0 & \# & 8.6 & 0.29 & -9.4 & & -1.7 & & 12.4 & 0.70 \\
\hline Orn & 23.6 & $\wedge$ & 13.3 & $\wedge$ & 6.7 & 0.39 & 8.8 & \# & 4.5 & & 2.58 & 0.35 \\
\hline Phe & 47.5 & $*$ & 12.8 & & 10.8 & 0.15 & 5.7 & & -1.1 & & 11.8 & 0.72 \\
\hline Pro & 28.6 & * & -2.6 & & 16.6 & 0.31 & 32.4 & & 0.4 & & 29.7 & 0.52 \\
\hline Ser & 17.2 & * & 1.0 & & 13.2 & 0.47 & 8.8 & & -28.1 & & 18.8 & 0.29 \\
\hline Thr & 31.3 & $*$ & 12.4 & & 9.7 & 0.30 & 26.3 & & 0.3 & & 17.4 & 0.40 \\
\hline Trp & 30.0 & \# & -3.9 & & 12.2 & 0.18 & & & & & & \\
\hline Tyr & 36.6 & * & 7.5 & & 13.1 & 0.25 & & & & & & \\
\hline Val & 70.0 & $*$ & 30.3 & & 12.4 & 0.15 & 116.1 & & -25.0 & $\wedge$ & 81.4 & 0.34 \\
\hline TEAA $^{4}$ & 516.5 & $*$ & 202.3 & & 111.0 & 0.18 & 237.5 & & -57.5 & & 191.2 & 0.38 \\
\hline TNEAA $^{4}$ & 310.2 & * & 54.0 & & 116.0 & 0.26 & 150.4 & & -177.1 & & 152.9 & 0.26 \\
\hline $\mathrm{TAA}^{4}$ & 826.7 & $*$ & 256.3 & $*$ & 219.0 & 0.20 & 387.9 & & -234.6 & & 343.4 & 0.32 \\
\hline
\end{tabular}

*, ^, \#, Differs from zero at $P<0.001$ to $0.05, P<0.05$ to 0.1 , or $P<0.11$ to 0.2 , (Trend), respectively.

${ }^{1}$ Probability of differing from zero.

${ }^{2}$ Standard error of the model least square means.

${ }^{3}$ Probability of difference between treatments within pools (FAA or PBAA).

${ }^{4}$ Total essential AA (TEAA), total nonessential AA (TNEAA), and total AA (TAA).

respectively. Glutamine appearance was negative and much more so in the low-protein diet. The fact that most of the Glu in that experiment disappeared from the intestine after $12 \mathrm{~m}$ (where basically no microbial activity takes place), and the fact that almost all of the arterial inflow of Glu did not show in the portal blood, indicates that the absorbed Glu, together with plasma Glu, were utilized by the GIT wall (intestine as well as rumen). As Glu is a glucogenic AA, it could be deaminated to ketoglutarate and enter the TCA cycle and serve as a source of energy for the GIT or could be incorporated into enzymes or tissue. This metabolic pattern indicates a great need for Glu that is not furnished to the GIT solely from absorption and has to come from other sources (i.e., from degraded plasma proteins or peptides). In the present experiment, Glu flux was positive in both groups of cows, and one could assume that the high corn starch content in both diets and especially with the higher starch digestion of the SFC starch (Delgado-Alorduy et. al., 2002b), contributed to a higher PDVF of energy or glucogenic compounds, hence saving on the energy supply from Glu sources. This was not the case in the present experiment, and the PDVF of glucogenic molecules and their energy (i.e., glucose, lactate, and propionate or total energy contributing compounds) was similar in SFC and SRC cows. (Sadik, 1997). As very little Glu is being absorbed from the GIT (Tagari and Bergman, 1978), it is concluded that the negative PDVF of PB-Glu in both groups of cows is accountable for the positive PDVF of Glu, after being subjected to peptidase activity either in blood or in the intestinal wall. The same phenomenon regarding the interrelations between the FAA and PBAA pools of Glu was recorded in the liver flux (Table 8), with a clearer trend observed in the splanchnic flux (Table 10). Glutamic acid seems to be degraded from its PB pool and added to the FAA pool.

The opposite may be true for other AA including Gly. Its flux as a FAA was relatively large, but its flux as a PBAA was 3.5 to 6 times larger and was much greater in the cows fed SFC. It may well be that the impact of Gly as a ketogenic AA with a relative high osmolarity is reduced when it is a component of the PBAA pool. Nevertheless, the dietary effect is apparently clear. 
Table 11. Mammary flux (uptake) of free (FAA) and peptide bound amino acids (PBAA) from plasma and milk AA secretion, (g/12 h), of cows fed steam-flaked (SFC) or steam-rolled corn (SRC) to density of 360 or $490 \mathrm{~g} / \mathrm{L}(\mathrm{n}=6)$.

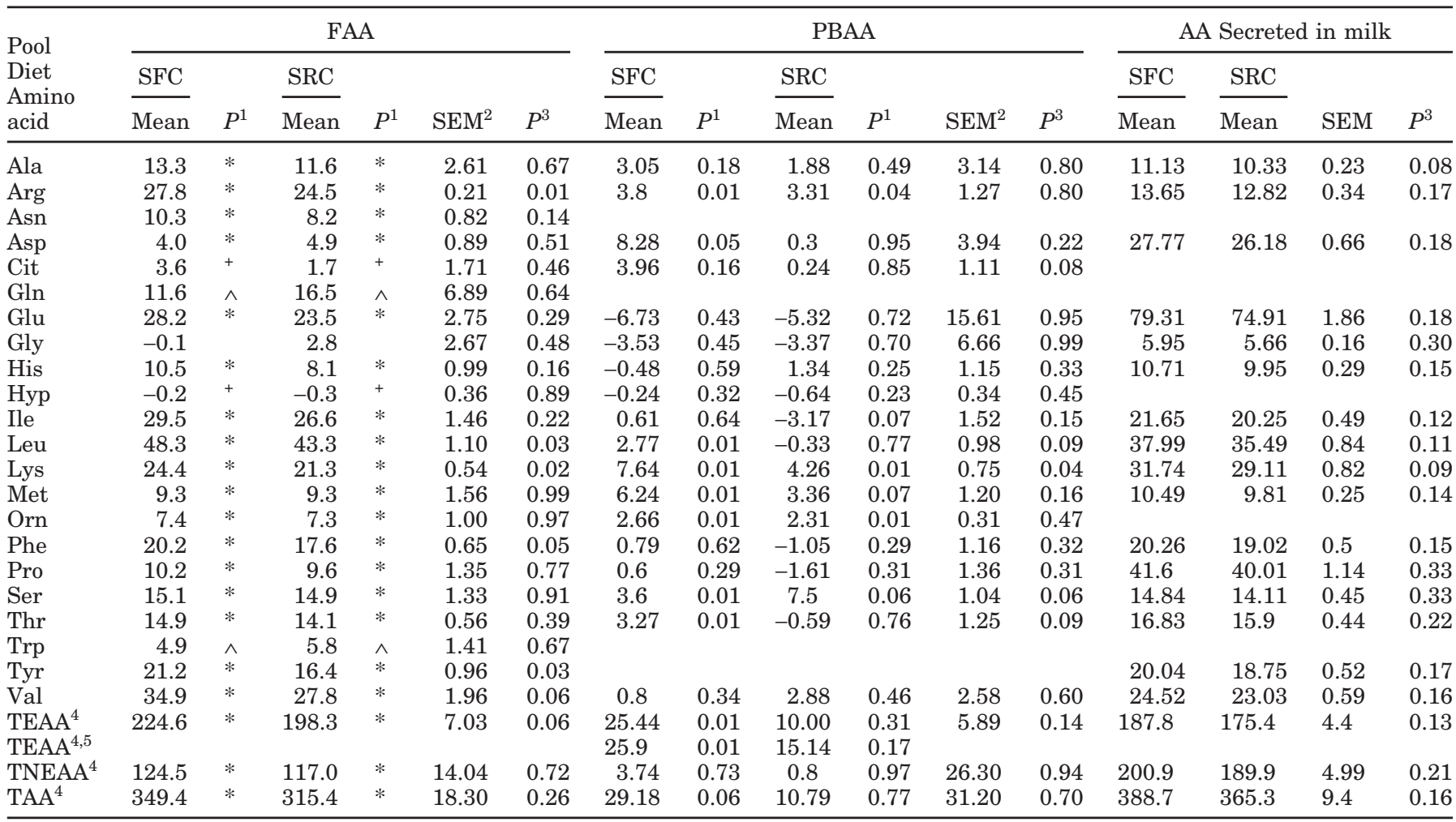

*, ^, Differs from zero at $P<0.001$ to $0.05, P<0.05$ to 0.1 , respectively.

${ }^{1}$ Probability of differing from zero.

${ }^{2}$ Standard error of the model least square means.

${ }^{3}$ Probability of difference between treatments within pools (FAA or PBAA).

${ }^{4}$ Total essential AA (TEAA), total nonessential AA (TNEAA), and total AA (TAA).

${ }^{5}$ Positive uptake only.

Large quantities of Gly are later removed from both plasma pools by the liver (Table 8), and very little appears in the FAA pool of the splanchnic flux; the splanchnic flux of PB-Gly is much smaller than the PDVF of PB-Gly.

Splanchnic flux (Table 10) of Arg and Val in SRC-fed cows is much smaller than in SFC-fed cows. This is despite the fact that large quantities of both PB-Arg and PB-Val were drawn from the peptides pool, presumably to provide these AA in support of the FAA pool. The same could be said about His in cows fed SRC, and despite the fact that the quantities of these AA drawn from the PBAA pool did not differ from zero, the phenomenon is noteworthy. The uptake of Arg could be explained by the need to support the urea cycle, and the PDVF of FAA Val was very small compared with cows fed SFC, and PDVF of PB-Val was negligible. It is assumed that uptake of this AA from the PBAA pool supplemented a shortage of this AA in the FAA pool. The PDVF of Arg (Table 7) in both treatments considerably surpasses the need for Arg excreted in milk, which is also true for its mammary flux (Table 11). Along with the positive flux of Arg as a FAA, there was a negative flux of PB-Arg. The pattern was similar for Cit. Both Arg and Cit play major roles in the urea cycle, whereby Cit is a precursor to Arg. Arginase present in the intestinal mucosal cells has the potential to degrade Arg to urea and Orn. Urea may be secreted back into the intestinal lumen (Tagari and Bergman, 1978) and Orn, which is absent from GIT content, appears in the PDVF in significant amounts in the FAA or PBAA pools. Arginine, together with Orn, can be used for the production of Pro. Verbeke et al. (1968) and Bruckental et al. (1991) reported that abomasal infusion of Pro in lactating dairy cows considerably reduced the MU of Arg. In the present experiment, Orn was extracted in significant amounts as the FAA and as PB-Arg. The uptake of PBArg was about $10 \%$ of its mammary flux as a FAA, but that of PB-Orn amounted to about $33 \%$ of its flux as FAA.

Relationship between PBAA and MU and milk secretion of AA. The MU of most FAA, especially EAA 
Table 12. Mammary extraction efficiency (MEE \%), of free (FAA) and peptide bound amino acids (PBAA) from plasma of cows fed corn grain steam-flaked (SFC) or steam-rolled (SRC) to density of 360 or $490 \mathrm{~g} / \mathrm{L}$ $(\mathrm{n}=6)$.

\begin{tabular}{|c|c|c|c|c|c|c|c|c|c|c|c|c|}
\hline \multirow{3}{*}{$\begin{array}{l}\text { Pool } \\
\text { Diet } \\
\text { Amino acid }\end{array}$} & \multicolumn{6}{|c|}{ FAA } & \multicolumn{6}{|c|}{ PBAA } \\
\hline & \multirow{2}{*}{$\frac{\mathrm{SFC}}{\text { Mean }}$} & \multirow[b]{2}{*}{$P^{1}$} & \multicolumn{2}{|l|}{ SRC } & \multirow[b]{2}{*}{$\mathrm{SEM}^{2}$} & \multirow[b]{2}{*}{$P^{3}$} & \multirow{2}{*}{$\frac{\mathrm{SFC}}{\text { Mean }}$} & \multirow[b]{2}{*}{$P^{1}$} & \multirow{2}{*}{$\frac{\mathrm{SRC}}{\text { Mean }}$} & \multirow[b]{2}{*}{$P^{1}$} & \multirow[b]{2}{*}{$\mathrm{SEM}^{2}$} & \multirow[b]{2}{*}{$P^{3}$} \\
\hline & & & Mean & $P^{1}$ & & & & & & & & \\
\hline Ala & 12.6 & * & 10.7 & * & 2.99 & 0.66 & 13.9 & & 4.1 & & 20.1 & 0.74 \\
\hline Arg & 50.1 & $*$ & 42.5 & * & 4.17 & 0.25 & 47.9 & $*$ & 32.4 & $*$ & 10.3 & 0.33 \\
\hline Asn & 58.8 & $*$ & 55.7 & * & 7.24 & 0.45 & & & & & & \\
\hline Asp & 45.0 & $*$ & 36.6 & $*$ & 3.65 & 0.37 & 42.7 & $*$ & -23.3 & & 41.3 & 0.31 \\
\hline Cit & 5.3 & & 1.9 & & 2.7 & 0.41 & 6.5 & & -0.5 & & 2.1 & 0.07 \\
\hline Gln & 15.1 & $\wedge$ & 19.3 & $\wedge$ & 6.96 & 0.65 & & & & & & \\
\hline Glu & 71.1 & $*$ & 63.4 & $*$ & 4.8 & 0.32 & -93.1 & & -87.5 & & 88.8 & 0.96 \\
\hline Gly & 0.9 & & 2.8 & & 3.54 & 0.72 & -2.1 & & -2.7 & & 4.5 & 0.92 \\
\hline His & 38.4 & $\wedge$ & 28.7 & $*$ & 4.29 & 0.17 & -3.3 & & 6.6 & & 5.7 & 0.28 \\
\hline Нур & -1.5 & & -2.4 & & 3.02 & 0.85 & -6.6 & & -14.4 & & 10.7 & 0.63 \\
\hline Ile & 39.9 & $*$ & 35.4 & $*$ & 3.54 & 0.41 & -22.9 & & -82.8 & & 184.2 & 0.82 \\
\hline Leu & 46.7 & $*$ & 41.6 & $*$ & 2.85 & 0.26 & 33.0 & * & -106.8 & & 80.9 & 0.26 \\
\hline Lys & 62.0 & $*$ & 56.5 & $*$ & 3.12 & 0.27 & 59.7 & * & 37.4 & * & 7.1 & 0.08 \\
\hline Met & 60.1 & $\wedge$ & 68.0 & $*$ & 13.6 & 0.69 & 71.0 & * & 48.2 & $*$ & 10.6 & 0.19 \\
\hline Orn & 41.6 & $\wedge$ & 39.3 & $*$ & 3.29 & 0.64 & 24.7 & $*$ & 19.8 & $*$ & 4.8 & 0.50 \\
\hline Phe & 49.5 & $*$ & 41.4 & $*$ & 3.64 & 0.17 & 166.2 & $\wedge$ & 114.0 & & 57.1 & 0.54 \\
\hline Pro & 19.7 & $\wedge$ & 17.9 & $*$ & 3.75 & 0.75 & 6.1 & & -49.5 & & 26.3 & 0.19 \\
\hline Ser & 39.9 & * & 37.3 & $*$ & 4.26 & 0.68 & 29.0 & * & 36.6 & $*$ & 6.1 & 0.41 \\
\hline Thr & 37.3 & $*$ & 29.8 & $*$ & 3.82 & 0.22 & 59.2 & * & 37.5 & & 49.3 & 0.77 \\
\hline Trp & 14.2 & $\wedge$ & 16.9 & $*$ & 4.4 & 0.69 & & & & & & \\
\hline Tyr & 40.0 & $*$ & 31.4 & $*$ & 2.6 & 0.07 & & & & & & \\
\hline Val & 24.9 & * & 20.8 & $*$ & 2.42 & 0.28 & 26.2 & & -28.3 & & 70.1 & 0.61 \\
\hline TEAA $^{4}$ & 39.3 & $*$ & 34.5 & * & 2.85 & 0.28 & 35.4 & $*$ & 10.7 & & 10.5 & 0.15 \\
\hline TNEAA $^{4}$ & 21.0 & $*$ & 19.5 & * & 3.46 & 0.77 & 0.3 & & -2.6 & & 10.9 & 0.86 \\
\hline $\mathrm{TAA}^{4}$ & 29.7 & $*$ & 26.8 & $*$ & 8.49 & 0.8 & 10.7 & $\wedge$ & 1.4 & & 9.5 & 0.52 \\
\hline
\end{tabular}

generally exceed the quantities excreted in the milk. Nevertheless, some will be extracted in quantities that only marginally exceed tissue needs or even in quantities that are short of tissue needs, and these are believed to be stochiometrically incorporated into milk proteins (Mepham, 1982). To examine the role of PBAA in meeting the requirement of $\mathrm{AA}$, correlation coefficients between MU of FAA or FAA + PBAA were examined and are presented in Table 13. It is apparent that there were correlations between MU of FAA and AA incorporation in milk for all AA except Gln, Gly, and Ser, with only a trend for Lys. Correlation coefficients and probability level improved when amounts of PBAA that were extracted by the mammary gland were included for Arg, His, Lys, and Met for both diets and for Thr for the SFC diet only. Correlation coefficients decreased when PBAA were included for the EAA, Ile, Leu, Phe, Thr, and Val and for NEAA Pro, Ser, Gly, Asp, and Ala. Two of the 5 EAA whose correlation coefficients were improved by including PBAA, namely Arg and Met, are known to be used by the mammary gland not only for milk AA synthesis, but for other purposes too. That many of the multiple methylation reactions involving Met occur extensively in the mammary gland is common knowledge.

Cultured bovine mammary epithelial (MAC-T) cells utilized Met from Met-containing dipeptides as sources of Met to support protein accretion, with the response ranging from 35 to $122 \%$ of the free Met growth response (Pan et al., 1996). Mammary tissue explants from lactating CD-1 mice were used to study the ability of Met-containing peptides to substitute for free Met for the synthesis of secreted proteins (Wang et al., 1996). The Met from all peptides was utilized and Met from 11 peptides promoted 15 to $76 \%$ greater synthesis of secreted proteins than did free Met. Results from in vivo experiments with lactating dairy goats indicate that many essential AA are taken up by the mammary gland as PBAA from the circulation and utilized for protein synthesis (Backwell et al., 1996; Bequette et al., 1999; Mabjeesh et al., 2000, 2001b). Mammary tissue from lactating cows was examined for the presence 
Table 13. Correlation between secretion of AA in milk and mammary uptake (MU) of FAA or FAA + PBAA. $(\mathrm{n}=12)$.

\begin{tabular}{|c|c|c|c|c|}
\hline \multirow[b]{2}{*}{ Amino acid } & \multicolumn{2}{|c|}{ MU of FAA } & \multicolumn{2}{|c|}{ MU of total AA } \\
\hline & $\mathrm{r}^{1}$ & $\mathrm{P}$ & $\mathrm{r}^{1}$ & $\mathrm{P}$ \\
\hline Ala & 0.594 & 0.042 & 0.200 & 0.534 \\
\hline Arg & 0.669 & 0.017 & 0.702 & 0.011 \\
\hline Asp & 0.603 & 0.038 & 0.020 & 0.950 \\
\hline Glu-gln vs. Gln FAA & 0.334 & 0.289 & 0.429 & 0.165 \\
\hline Glu-gln vs. Glu FAA & 0.631 & 0.028 & & \\
\hline Gly & -0.058 & 0.859 & 0.092 & 0.775 \\
\hline His & 0.806 & 0.002 & 0.844 & 0.001 \\
\hline Ile & 0.770 & 0.003 & 0.680 & 0.015 \\
\hline Leu & 0.792 & 0.002 & 0.680 & 0.015 \\
\hline Lys & 0.477 & 0.117 & 0.526 & 0.079 \\
\hline Met & 0.666 & 0.018 & 0.795 & 0.002 \\
\hline Phe & 0.797 & 0.002 & 0.257 & 0.421 \\
\hline Pro & 0.514 & 0.087 & 0.445 & 0.147 \\
\hline Pro vs. (Arg + Pro) FAA & 0.685 & 0.014 & & \\
\hline Ser & 0.123 & 0.704 & -0.281 & 0.377 \\
\hline Thr & 0.763 & 0.004 & 0.653 & 0.021 \\
\hline $\mathrm{Thr}^{2}$ & 0.753 & 0.084 & 0.793 & 0.060 \\
\hline Tyr & 0.801 & 0.002 & & \\
\hline Val & 0.668 & 0.018 & 0.411 & 0.184 \\
\hline Sum $\mathrm{EAA}^{3}$ & 0.849 & 0.001 & 0.826 & 0.001 \\
\hline Sum NEAA ${ }^{3}$ & 0.670 & 0.017 & 0.379 & 0.224 \\
\hline Sum TAA $^{3}$ & 0.820 & 0.001 & 0.703 & 0.011 \\
\hline
\end{tabular}

${ }^{1}$ The correlation between milk secretion of AA and MU of FAA or FAA + PBAA.

${ }^{2}$ For SFC cows only $(\mathrm{n}=6)$.

${ }^{3}$ Total essential AA (TEAA), total nonessential AA (TNEAA), and total AA (TAA).

of mRNA for a peptide transport protein (PepT1; Chen et al., 1999). None was detected, indicating that utilization of PBAA by mammary tissue may not involve absorption of these. Recently, evidence was reported for the presence of mRNA for aminopeptidase $\mathrm{N}$ in the mammary gland of goats and cows (Mabjeesh et al., 2001a). This enzyme is imbedded in the cell membrane and is an exopeptidase that cleaves $\mathrm{N}$-terminal AA from peptides. The presence of aminopeptidase $\mathrm{N}$ in the cell membrane of the mammary epithelium may explain how AA from PBAA in the circulation are internalized by the mammary gland.

It is well accepted that the first limiting AA in the diet of lactating cows for milk protein synthesis are Lys and Met, and recently His was suggested as well (Vanhatalo et al., 1999). Indeed, the largest relative amounts that were extracted from the PBAA pool in BOTH treatments were those of Lys and Met, whereas those of His in both treatments and Lys in the SRC diet were still in marginal or short supply. These shortages might be satisfied from 2 additional sources: degradation of peptides (or proteins) larger than included in the PBAA pool $(3 \mathrm{kDa})$ and from blood cells. That plasma proteins might be a source of AA for tissues was reported previously (Danilson et al., 1987b; McCormick and Webb, 1987). Results from several studies indicate that blood cells pose the ability for interorgan transfer of FAA (McCormick and Webb, 1982; Danilson et al., 1987a; Hanigan et al., 1991), whereas others do not (Mackle et al., 2000). The extent to which blood cells play a role in the interorgan transfer of FAA might be variable and dependent on the physiological status of the animal. Hanigan et al. (1991) reported that blood cells contributed sizable amounts of His, and to a lesser extent, Lys and Met to the total pool of AA extracted by the mammary gland of lactating cows. The fact that such large proportions and quantities of Lys and much larger proportions of Met were extracted from the plasma PBAA pool in the present study, despite the quoted potential contribution of Lys and Met from blood cells, further emphasizes the role of the plasma PBAA pool as a source for meeting mammary requirements of EAA or even total AA.

\section{CONCLUSIONS}

Milk and milk protein yields increased significantly in lactating dairy cows at midlactation with steam flaking of corn compared with steam rolling. This improvement in milking performance was the result of a substantial increase in PDV flux and splanchnic flux of FAA and PBAA, and a significant increase in MU of AA from these two pools. Essential PBAA concentrations, expressed as a proportion of essential FAA, varied between 7.5 to $14 \%$. From 37 to $101 \%$ of PDV flux and $\mathrm{MU}$ of essential AA were in the form of PBAA and these 
supplemented shortages of AA from the FAA pool either for milk protein production or other metabolic functions. A dietary effect on the AA profile of the PDV flux of PBAA was apparent. More studies are needed to substantiate the effect of diet on the extent and profile of PDV flux of FAA and PBAA and the release from the latter free AA to their pool in blood. Quantifying diet effects on PDV flux of FAA and PBAA, may lead to improvements in diet formulation and efficiency of dietary protein utilization.

\section{ACKNOWLEDGMENTS}

The authors wish to thank the United States-Israeli Binational Agricultural Research and Development Fund (BARD), USDA-ARS, Beltsville, MD, for its partial financial support of this research project. Thanks are also extended to Hillary Voet, Department of Agriculture Economy, Faculty of Agriculture, The Hebrew University of Jerusalem for carrying out the statistical analyses.

\section{REFERENCES}

Al-Dehne, A., J. T. Huber, R. Wanderly, C. B. Theurer, M. Passaraki, and D. DeYong. 1997. Incorporation of recycled urea N into ruminal bacteria flowing to the small intestine of dairy cows fed a high grain or high forage diet. Anim. Feed Sci. Technol. 68:327-338.

AFRC. 1991. Agriculture and Food Recearch Council: Technical Committee on Responses to Nutrients. Report number 8. Voluntary intake of cattle. Nutr. Abs. Rev. (Ser. B) 61:815-823.

Backwell, F. R. C., B. J. Bequette, D. Wilson, J. A., Matcalf, M. F. Franklin, D. E. Beever, G. E. Lobley, and J. C. MacRae. 1996. Evidence for utilization of peptides for milk protein synthesis in the lactating dairy goat in vivo. Am. J. Physiol. 271:R955-R960.

Bequette, B. J., F. R. C. Backwell, C. E. Kyle, A. G. Calder, V. Buchan, L. A. Crompton, J. France, and J. C. MacRae. 1999. Vascular sources of phenylalanine, tyrosine, lysine, and methionine for casein synthesis in lactating goats. J. Dairy Sci. 82:362-377.

Bidlingmeyer, B. A., S. A. Cohen, and T. L. Tarvin. 1984. Rapid analysis of amino acids using pre-column derivatization. J. Chromatogr. 336:93-104.

Brockman, R. P., and E. N. Bergman. 1975. Quantitative aspects of insulin secretion and its hepatic and renal removal in sheep. Am. J. Physiol. 229:1338-1343.

Bruckental, I., I. Ascarelli, B. Yosif, and E. Alumot. 1991. Effect of duodenal proline infusion on milk production and composition in dairy cows. Anim. Prod. 53:299-303.

Chen, H., E. A. Wong, and K. E. Webb, Jr. 1999. Tissue distribution of a peptide transporter mRNA in sheep, dairy cows, pigs, and chickens. J. Anim. Sci. 77:1277-1283.

Danilson, D. A., K. E. Webb, Jr., and J. H. Herbein. 1987a. Transport and hindlimb exchange of plasma and blood-cell amino acids in calves fed soy- or urea-based purified diets. J. Anim. Sci. 64:1842-1851.

Danilson, D. A., K. E. Webb, Jr., and J. H. Herbein. 1987b. Transport and hindlimb exchange of peptide and serum protein amino acids in calves fed soy- or urea-based purified diets. J. Anim. Sci. 64:1852-1857.

Delgado-Elorduy, A., C. B. Theurer, J. T. Huber, A. Alio, O. Lozano, M. Sadik, P. Cuneo, D. DeYoung, J. Simas, K. E. Webb, Jr., and H. Tagari. 2002a. Splanchnic and mammary nitrogen metabolism by dairy cows fed dry-rolled or steam-flaked sorghum grain. J. Dairy Sci. 85:148-159.
Delgado-Elorduy, A., C. B. Theurer, J. T. Huber, A. Alio, O. Lozano, M. Sadik, P. Cuneo, D. DeYoung, J. Simas, J. E. P. Santos, L. Nussio, C. Nussio, K. E. Webb, Jr., and H. Tagari. 2002b. Splanchnic and mammary nitrogen metabolism by dairy cows fed steamrolled or steam-flaked corn. J. Dairy Sci. 85:160-168.

Eisenman, J. H., G. B. Huntington, and C. L. Ferrell. 1987. Blood flow to hindquarters measured by transint time ultrasound and indicator delusion. J. Dairy Sci. 70:1385-1390.

Elwyn, D. H. 1966. Distribution of amino acids between plasma and red blood cells in the dog. Fed. Proc. 25:854-857.

Flatt, W. P., L. A. Moe, L. A. Moore, N. E. Hoover, R. P. Lehmann, R. Orskov, and R. W. Hemken. 1969. Energy utilization by high producing dairy cows. I. Experimental design, ration composition, digestibility data, and animal performance during energy balance. Pages 221-250 in Energy Metabolism in Farm Animals. K. L. Blaxter, J. Kiehanovski, and J. E. Tonrok, eds. Oriol Press Ltd., Newcastle Upon Tyne, UK.

Guinard, J., and H. Rulquin. 1994. Effect of graded level of duodenal infusions of casein on mammary uptake in lactating cows. 2. Individual amino acids. J. Dairy Sci. 77:3304-3315.

Haibel, G. K., L. A. Guilbault, P. Villeneuve, and W. W. Thatcher. 1989. Aortic catheterization in cattle via the costoabdominal artery and validation for progesterone and estradiol-17 sample collection. Am. J. Vet. Res. 50:1923-1925.

Hanigan, M. D., C. C. Calvert, E. J. DePeters, B. L. Reis, and R. L. Baldwin. 1991. Whole blood and plasma amino acid uptakes by lactating bovine mammary glands. J. Dairy Sci. 74:2484-2490.

Huntington, G. B. 1989. Hepatic urea synthesis and site and rate of urea removal from blood of beef steers fed alfalfa hay or a high concentrate diet. Can. J. Anim. Sci. 69:215-223.

Katz, M. L., and E. N. Bergman. 1969. Hepatic and portal metabolism of glucose, free fatty acids, and ketone bodies in the sheep. Am. J. Physiol. 216:953-960.

Koeln, L. L., T. G. Schlaghack, and K. E. Webb, Jr. 1993. Amino acid flux across the gastrointestinal tract and liver of calves. J. Dairy Sci. 76:2275-2285.

Lapierre, H., J. F. Bernier, P. Dubreuil, C. K. Reynolds, C. Farmer, D. R. Ouellet, and G. E. Lobley. 2000. The effect of feed intake level on splanchnic metabolism in growing beef steers. J. Anim. Sci. 78:1084-1099.

Mabjeesh, S. J., M. Cohen, O. Gal-Garber, A. Shamay, and Z. Uni. 2001a. Amino peptidase gene expression in caprine mammary gland: A possible role in peptide-bound amino acid uptake. J. Dairy Sci. 84(Suppl. 1):313. (Abstr.)

Mabjeesh, S. J., C. E. Kyle, J. C. MacRae, and B. J. Bequette. 2000. Lysine metabolism by the mammary gland of lactating goats at two stages of lactation. J. Dairy Sci. 83:996-1003.

Mabjeesh, S. J., C. E. Kyle, J. C. MacRae, M. D. Hanigan, and B. J. Bequette. 2001b. Vascular sources of amino acids for milk protein synthesis in goats at two stages of lactation. J. Dairy Sci. 84:919-929.

Mackle, T. R., D. A. Dwyer, K. L. Ingvartsen, P. Y. Chouinard, D. A. Ross, and D. E. Bauman. 2000. Evaluation of whole blood and plasma in the interorgan supply of free amino acids for the mammary gland of lactating dairy cow. J. Dairy Sci. 83:1300-1309.

McCormick, M. E., and K. E. Webb, Jr. 1982. Plasma free, erythrocyte free and plasma peptide amino acid exchange of calves in steady state and fasting metabolism. J. Nutr. 112:276-282.

McCormick, M. E., and K. E. Webb, Jr. 1987. Serum proteins as carriers of amino acids to and from the hindlimbs of fed and fasted calves. J. Anim. Sci. 64:586-593.

Metcalf, J. A., D. Wray-Cahen, E. E. Chattle, J. D. Sutton, D. E. Beever, L. A. Crompton, J. C. MacRea, B. J. Bequette, and F. R. C. Backwell. 1996. The effect of dietary crude protein as protected soybean meal on mammary metabolism in lactating dairy cows. J. Dairy Sci. 79:603-611.

Mepham, T. B. 1982. Amino acid utilization by lactating mammary gland. J. Dairy Sci. 65:287.

Moe, L. A., and H. Tyrrell. 1979. Effect of endosperm type on incremental energy value of corn grain for dairy cows. J. Dairy Sci. 62:447-454. 
National Research Council. 2001. Nutrient Requirements of Dairy Cattle. 7th rev. ed. Natl. Acad. Sci., Washington, DC.

Oliviera, J. S., J. T. Huber, D. Ben-Ghedalia, R. S. Swingle, C. B. Theurer, and M. Passaraki. 1995. Influence of sorghum grain processing on performance of lactating dairy cows. J. Dairy Sci. 76:575-581.

Pan, Y. L., P. K. Bender, R. M. Akers, and K. E. Webb, Jr. 1996. Methionine-containing peptides can be used as methionine sources for protein accretion in cultured $\mathrm{C}_{2} \mathrm{C}_{12}$ and MAC-T cells. J. Nutr. 126:232-241.

Plascenica, A., and R. A. Zinn. 1996. Influence of flake density on the feeding value of steam-processed corn in diets for lactating cows. J. Anim. Sci. 74: 310-316.

Remond, D., L. Bernard, and C. Poncet. 2000. Free and peptide amino net flux across the rumen and mesenteric- and portal-drained viscera of sheep. J. Anim. Sci. 78:1960-1972.

Sadik, M. S. 1997. Post-absorptive energy metabolism of lactating dairy cows fed differently-processed corn and sorghum grains. Ph.D. Diss. Univ. Arizona, Tucson.

Schwab, C. C., L. D. Satter, and A. B. Clay. 1976. Response of lactating dairy cows to abomasal infusion of amino acids. J. Dairy Sci. 59:1254-1261.

Seal, C., and D. S. Parker. 1996. Effect of intraruminal propionic acid infusion of mesenteric- and portal-drained viscera in growing steers fed forage diets. II. Ammonia, urea, amino acids, and peptides. J. Anim. Sci. 74:245-256.

Tagari, H., and E. N. Bergman. 1978. Intestinal disappearance and portal blood appearance of amino acids in sheep. J. Nutr. 108:790-803.

Theurer, C. B., J. T. Huber, and A. Delgado-Alurdoy. 1997. Steamflaked vs steam-rolled corn for dairy cows. Pages 79-91 in Proc. 4-State Appl. Nutr. Manage. Conf., LaCrosse, WI.

Theurer, C. B., J. T. Huber, A. Delgado-Alurdoy, and R. Wonderly. 1999. Invited review: Summary of steam-flaking corn or sorghum grain for lactating dairy cows. J. Dairy Sci. 82:1950-1999.

Vanhatalo, A., P. Huhtanen, V. Toivonen, and T. Varvikko. 1999. Response of dairy cows fed grass silage diets to abomasal infusions of histidine alone or in combinations with methionine and lysine. J. Dairy Sci. 82:2674-2685.

Verbeke, R., G. Peeters, A. M. Massart-Leen, and G. Cocquyt. 1968. Incorporation of DL[2-14C] ornithine and DL-[5-14C] arginine in milk constituents by the isolated sheep udder. Biochem. J. 106:719-724

Wang, S., K. E. Webb, Jr., and R. M. Akers. 1996. Peptide-bound methionine can be a source of methionine for the synthesis of secreted proteins by mammary tissue explants from lactating mice. J. Nutr. 126:1662-1672.

Webb, K. E., Jr., D. B. DiRienzo, and J. C. Matthews.1993. Recent developments in gastrointestinal absorption and tissue utilization of peptides: A review. J. Dairy Sci. 76:351-361. 